\title{
Simulating aerosol microphysics with the ECHAM/MADE GCM - Part I: Model description and comparison with observations
}

\author{
A. Lauer ${ }^{1}$, J. Hendricks ${ }^{1}$, I. Ackermann ${ }^{2}$, B. Schell ${ }^{2}$, H. Hass ${ }^{2}$, and S. Metzger ${ }^{3}$ \\ ${ }^{1}$ DLR Institut für Physik der Atmosphäre, Oberpfaffenhofen, Wessling, Germany \\ ${ }^{2}$ Ford Research Center Aachen, Aachen, Germany \\ ${ }^{3}$ Max Planck Institute for Chemistry, Mainz, Germany
}

Received: 2 May 2005 - Published in Atmos. Chem. Phys. Discuss.: 2 September 2005

Revised: 15 November 2005 - Accepted: 15 November 2005 - Published: 7 December 2005

\begin{abstract}
The aerosol dynamics module MADE has been coupled to the general circulation model ECHAM4 to simulate the chemical composition, number concentration, and size distribution of the global submicrometer aerosol. The present publication describes the new model system ECHAM4/MADE and presents model results in comparison with observations. The new model is able to simulate the full life cycle of particulate matter and various gaseous particle precursors including emissions of primary particles and trace gases, advection, convection, diffusion, coagulation, condensation, nucleation of sulfuric acid vapor, aerosol chemistry, cloud processing, and size-dependent dry and wet deposition. Aerosol components considered are sulfate $\left(\mathrm{SO}_{4}\right)$, ammonium $\left(\mathrm{NH}_{4}\right)$, nitrate $\left(\mathrm{NO}_{3}\right)$, black carbon $(\mathrm{BC})$, particulate organic matter (POM), sea salt, mineral dust, and aerosol liquid water. The model is numerically efficient enough to allow long term simulations, which is an essential requirement for application in general circulation models. Since the current study is focusing on the submicrometer aerosol, a coarse mode is not being simulated. The model is run in a passive mode, i.e. no feedbacks between the MADE aerosols and clouds or radiation are considered yet. This allows the investigation of the effect of aerosol dynamics, not interfered by feedbacks of the altered aerosols on clouds, radiation, and on the model dynamics.
\end{abstract}

In order to evaluate the results obtained with this new model system, calculated mass concentrations, particle number concentrations, and size distributions are compared to observations. The intercomparison shows, that ECHAM4/MADE is able to reproduce the major features of the geographical patterns, seasonal cycle, and vertical distributions of the basic aerosol parameters. In particular, the model performs well under polluted continental conditions in the northern hemispheric lower and middle troposphere.

Correspondence to: A. Lauer

(axel.lauer@dlr.de)
However, in comparatively clean remote areas, e.g. in the upper troposphere or in the southern hemispheric marine boundary layer, the current model version tends to underestimate particle number concentrations.

\section{Introduction}

Aerosols play an important role in the Earth's atmosphere. Due to absorption and scattering of solar radiation (direct effect) as well as their importance for cloud formation, cloud microphysical properties, and cloud lifetime (indirect effect), aerosols are highly relevant to the Earth's climate. Major uncertainties in predicting the anthropogenic climate change arise in particular from the aerosol indirect effect (IPCC, 2001). Special difficulties of numerical simulations of the atmosphere are caused by the complex interactions between aerosol particles, atmospheric dynamics and cloud microphysical processes which are relevant for a large range of spatial and temporal scales. Apart from the effect of aerosols on climate, aerosol particles have an important influence on atmospheric chemistry. Various heterogeneous chemical reactions such as hydrolysis of $\mathrm{N}_{2} \mathrm{O}_{5}$ are enabled in presence of surface area provided by particulate matter. Moreover, aerosols affect the visibility and are known to be harmful to human health in polluted areas.

Up to now, most climate models consider aerosols in the form of prescribed climatologies or predictions of the aerosol mass concentration only. For instance, the GCM ECHAM (Roeckner et al., 1996, 2003) uses a climatology (Tanre et al., 1984) as input for computing the radiative transfer. Common extensions of climate models implement an explicit prediction of the mass concentrations of various aerosol components (e.g. Feichter et al., 1996; Lohmann et al., 1999; Adams et al., 1999). Nevertheless, the aerosol number concentration has to be obtained diagnostically from climatological number size distributions in these models. This can be a large source

(C) 2005 Author(s). This work is licensed under a Creative Commons License. 
of uncertainty, since the optical properties of the aerosol particles, the ability of aerosols to serve as cloud condensation nuclei, as well as long-range transport and health effects of aerosols depend particularly on the particle size.

With increasing computational capacities of current super computers, more detailed simulations of atmospheric particulate matter within global models have become possible. First steps have already been done. For instance, Gong and Barrie (1997) and Schulz et al. (1998) simulated the global distribution of sea salt and mineral dust, respectively, for different size classes. Jacobson (2001) introduced a global model, which enables the prediction of the size distribution of various particulate species, but which has a very high demand of computational resources. Adams and Seinfeld (2002) extended a global climate model to simulate sulfate aerosols including predictions of the size distribution. Most recently, the climate model ECHAM has been extended by the aerosol module HAM, which takes into account sulfate $\left(\mathrm{SO}_{4}\right)$, black carbon (BC), particulate organic matter (POM), sea salt, and mineral dust and which allows the simulation of particle size distribution (Stier et al., 2005). As an alternative to this aerosol module, we extended ECHAM by the Modal Aerosol Dynamics module for Europe (MADE) (Ackermann et al., 1998). The major differences between HAM and MADE can be characterized as follows: HAM considers seven log-normally distributed modes, each representing a specific aerosol composition in a fixed size-range. In contrast, MADE considers a trimodal log-normal size distribution and assumes a perfect internal mixture of the different aerosol compounds. The log-normal modes predicted by MADE are not fixed to prescribed size-ranges as in the case of HAM. The computer capacities saved by MADE due to the smaller number of modes is spend to simulate a larger number of aerosol compounds. While MADE predicts the full $\mathrm{SO}_{4} / \mathrm{NO}_{3} / \mathrm{NH}_{4} / \mathrm{H}_{2} \mathrm{O}$ system, HAM currently neglects nitrate $\left(\mathrm{NO}_{3}\right)$ and considers a prescribed degree of $\mathrm{SO}_{4}$ neutralization by ammonium $\left(\mathrm{NH}_{4}\right)$.

The use of modal aerosol modules instead of sectional models, which highly resolve the particle size distribution, is necessary regarding the huge computer capacities required for global climate simulations. Nevertheless, simplifying the aerosol size distribution by the assumption of log-normal size modes is a source of uncertainty. Therefore the use of different and independent modal aerosol modules (e.g. HAM and MADE) in a similar model environment is an important and reasonable step to evaluate the sensitivity of the modeled global aerosol characteristics to different numerical approaches. Current uncertainties in predicting aerosol properties and aerosol related effects on global climate can be estimated, if results obtained with a particular model are compared to simulations performed with other global aerosol models. ECHAM4/MADE can contribute to such model ensembles to make further progress.

The present paper describes the new model system ECHAM4/MADE (Sect. 2), gives a brief overview on the global distribution of simulated aerosol components, and presents global simulations of the aerosol composition and size distribution, which are compared to observational data (Sect. 3). The main conclusions of this study are summarized in Sect. 4.

\section{Model description}

The base model consists of the general circulation model (GCM) ECHAM including enhanced cloud microphysics and an aerosol mass module (Sect. 2.1). These components have been coupled with the aerosol dynamics module MADE (Sect. 2.2) resulting in the new model system ECHAM4/MADE.

\subsection{The ECHAM GCM}

The atmospheric general circulation model (GCM) ECHAM4 (Roeckner et al., 1996) is the fourth generation of a spectral climate model, based on a numerical model for medium range weather forecasts by the European Centre for Medium-Range Weather Forecasts (ECMWF). The model has been adapted for running climate simulations by the Max Planck Institute for Meteorology and the University of Hamburg (Hamburg, Germany). ECHAM can be run at different resolutions. For the present study, ECHAM is applied in spectral T30 spatial resolution. The corresponding transformation to a Gaussian grid delivers a horizontal resolution of approximately $3.75^{\circ} \times 3.75^{\circ}$ (longitude $\times$ latitude). The standard version of ECHAM4, which is the basis for this study, has 19 non-equidistant vertical layers, with the highest resolution in the boundary layer. The vertical coordinate system is a hybrid $\sigma$-pressure system $\left(\sigma=\mathrm{p} / \mathrm{p}_{0}\right)$, with the top layer centered around $10 \mathrm{hPa}(\approx 30 \mathrm{~km})$. ECHAM is based on the primitive equations. The basic prognostic variables are vorticity, (horizontal) divergence of the wind field, logarithm of the surface pressure, and the mass mixing ratios of water vapor, cloud water, as well as optional tracer mixing ratios. Advection of water vapor, cloud water, and the optional tracers is calculated using a semi-Lagrangian scheme (Rasch and Williamson, 1990). Time integration of the model equations is calculated using a semi-implicit leap frog scheme with a time step of $30 \mathrm{~min}$ (T30 resolution). The radiation scheme considers water vapor, ozone, $\mathrm{CO}_{2}$, $\mathrm{N}_{2} \mathrm{O}, \mathrm{CH}_{4}, 16 \mathrm{CFCs}$, aerosols, and clouds. Convection is parameterized following the bulk mass flux concept by Tiedtke (1989). For this study, the numerics of convection are modified according to Brinkop and Sausen (1997). The cloud scheme applied here considers cloud liquid water, cloud ice, and the number concentrations of cloud droplets and ice crystals as prognostic variables (Lohmann et al., 1999; Lohmann and Kärcher, 2002).

For the present study, the model was run in quasiequilibrium mode (so-called time-slice experiment). To this 


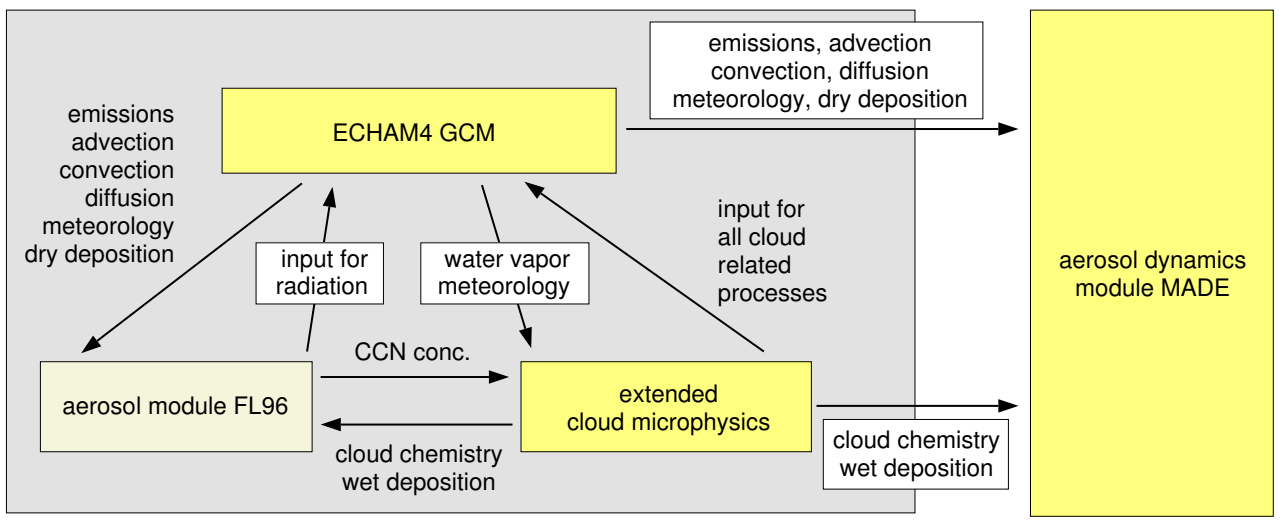

Fig. 1. Schematic overview of the model configuration used. The aerosol dynamics module MADE is currently operated in passive mode, neglecting feedbacks between MADE aerosol and clouds/radiation.

end, sea surface temperature (SST), greenhouse gas concentrations, and other boundary conditions were prescribed according to measurements performed around 1990. Thus, the average of several simulated model years represents the year 1990. The model simulation presented here was integrated 10 years following a 4-year spin-up period, which has been discarded when analyzing the model results.

\section{Aerosol mass module FL96}

In the model experiment described here, the new aerosol module MADE was run in passive mode, neglecting feedbacks of MADE aerosol to cloud properties or radiation. Before such feedbacks will be considered, the quality of the MADE aerosol has to be approved, which is the motivation of this study. To drive the cloud and radiation scheme for the simulations described here, an aerosol mass module developed for ECHAM previously is applied. This aerosol mass module (hereafter referred to as aerosol module FL96) calculates the mass concentrations of sulfate, methane sulphonic acid (MSA), mineral dust, sea salt, and black and organic carbon. It is based on the work of Feichter et al. (1996), Lohmann et al. (1999), Lohmann (2002), and Feichter and Roeckner (2004). The full life cycle of the aerosol mass including emission, atmospheric residence, and loss due to dry or wet deposition is considered. Figure 1 shows a schematic overview of the model configuration currently used, with MADE run in passive mode.

In FL96, the emission of sea salt (mass) at the ocean surfaces is calculated from the modeled $10 \mathrm{~m}$ wind speed following Monahan et al. (1986). The emission data of mineral dust have been obtained from a multiannual integration with the global model GOCART (Chin et al., 2000), performed by Ginoux et al. (2001). Carbonaceous aerosol consists of black and organic carbon. For both components, FL96 distinguishes between hydrophobic and hydrophilic particles. $80 \%$ of all BC-particles and 50\% of all OC-particles emitted are assumed to be hydrophobic (Cooke et al., 1999; Lohmann et al., 1999). Only the hydrophilic fractions of BC and POM are subject to potential removal by wet deposition. Aging of carbonaceous particles, i.e. conversion of hydrophobic into hydrophilic BC/POM, is parameterized as an exponential decay using an e-folding time of $24 \mathrm{~h}$ for both types of particles (Lohmann et al., 1999).

The sulfur chemistry of the aerosol module FL96 includes the gas phase production of sulfuric acid vapor and the formation of sulfate in cloud droplets. It is distinguished between daylight and night time chemistry. During day time, $\mathrm{SO}_{2}$ (either from emissions or from previous oxidation of DMS or COS) is oxidized by $\mathrm{OH}$ to form $\mathrm{H}_{2} \mathrm{SO}_{4}$ in the gas phase or by $\mathrm{O}_{3}$ or $\mathrm{H}_{2} \mathrm{O}_{2}$ in the liquid phase of cloud droplets to form $\mathrm{SO}_{4}$. At night, $\mathrm{SO}_{2}$ is oxidized to $\mathrm{SO}_{4}$ in the liquid phase only. Also during nighttime, $\mathrm{SO}_{2}$ can either be emitted directly or produced by oxidation of DMS. Further details on the sulfur chemistry and the reactions considered can be found in Feichter et al. (1996).

\subsection{The aerosol dynamics module MADE}

\subsubsection{Basic ideas}

The Modal Aerosol Dynamics module for Europe (MADE) is based on the Regional Particulate Model (RPM) by Binkowski and Shankar (1995). It has been adapted to European conditions and modified by Ackermann et al. (1998) for use in the regional scale European Air Pollution Dispersion model system EURAD (Ebel et al., 1997). The number concentration $n$ of the aerosol is represented by the sum of three log-normally distributed modes following the concept of Whitby et al. (1991):

$n(\ln d)=\sum_{k=1}^{3} \frac{N_{k}}{\sqrt{2 \pi} \ln \sigma_{g, k}} \exp \left(-\frac{1}{2} \frac{\left(\ln d-\ln d_{g, k}\right)^{2}}{\left(\ln \sigma_{g, k}\right)^{2}}\right)$

where $N_{k}$ is the total number concentration of mode $k, d$ is the particle diameter, $d_{g, k}$ the median diameter of the mode 


\section{ECHAM4/MADE}

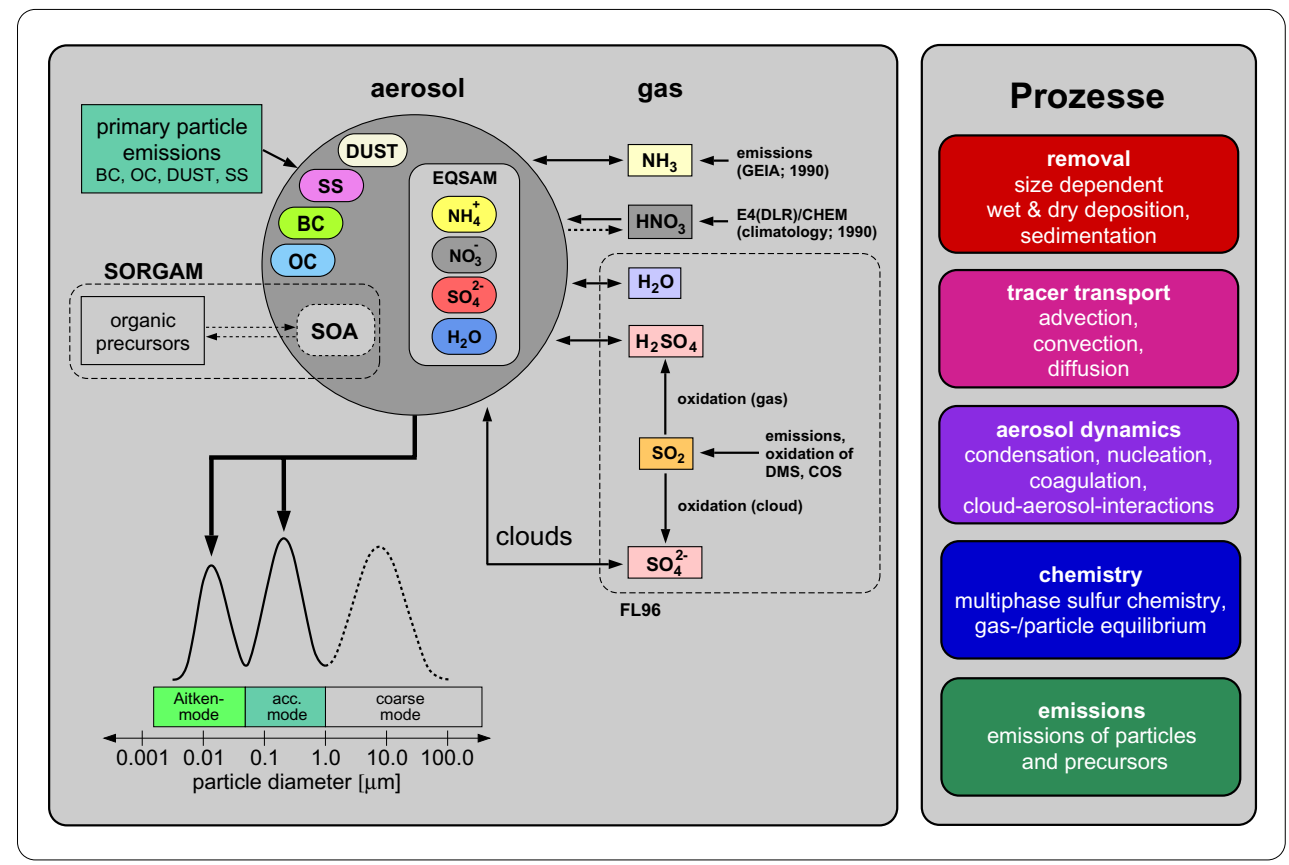

Fig. 2. Schematic overview of the aerosol dynamics module MADE and the relevant processes considered by the model system ECHAM4/MADE. The coarse mode and the calculation of secondary organic aerosols (SOA) have been disabled for this study.

and $\sigma_{g, k}$ the geometric standard deviation. As this study focuses on the submicrometer particles, the coarse mode (mode 3 ) is not considered here. Thus, the aerosol population is described with two modes, the Aitken and the accumulation mode. Due to numerical reasons, MADE solves the equations governing the evolution of the aerosol population with time not directly for $N, d_{g}$ and $\sigma_{g}$, but for the 0 th, 3rd and 6th integral moments of the log-normal distribution for each mode. The $k$ th integral moment $M_{k}$ is defined as:

$M_{k}=\int_{-\infty}^{\infty} d^{k} n(\ln d) \mathrm{d}(\ln d)$

The 0th integral moment equals the total number concentration $N$. In the MADE version applied here, the geometric standard deviations of both modes are kept constant to reduce the numerical expenses. Thus, it is sufficient to solve differential equations for $M_{0}$ and $M_{3}$ only. The geometric standard deviations are chosen as 1.7 and 2.0 for the Aitken and the accumulation mode, respectively. The standard deviation of typical atmospheric aerosol ranges between approximately 1.2 and 2.2 (Jaenicke, 1993). Typical variations of $\sigma_{g}$ are less than those of the two other parameters of the log-normal distribution $d_{g}$ and $N$. Thus, the use of fixed $\sigma_{g}$ allows for reducing the overall computational expenses without loosing too much accuracy.

All particles within the same mode are assumed to contain an internal mixture of various compounds.
ECHAM4/MADE considers sulfate $\left(\mathrm{SO}_{4}\right)$, ammonium $\left(\mathrm{NH}_{4}\right)$, nitrate $\left(\mathrm{NO}_{3}\right)$, aerosol liquid water $\left(\mathrm{H}_{2} \mathrm{O}\right)$, black carbon (BC), and organic carbon (OC). Additionally, accumulation mode particles can also contain mineral dust (DUST) and sea salt (SS). The assumption of a perfect internal mixture within the different size modes is a simplification, which reduces the computational burden significantly. In general, the degree of internal mixture depends on the residence time of the aerosol in the atmosphere. In polluted continental regions, the characteristic time of the transformation from external to internal mixture is short (in the order of hours) (Raes et al., 2000). This time scale is comparable to the time needed for the emitted particles to disperse into the large volume covered by the large-scale model grid boxes. However, under clean conditions or in case of strong nucleation, the assumption of an internal mixture introduces some uncertainties to the predicted aerosol properties. This can be of particular relevance when considering optical properties and radiative effects of aerosols.

The processes relevant to the aerosol life cycles in ECHAM4/MADE will be described briefly in the following. Figure 2 provides a schematic overview of these processes and of MADE.

\subsubsection{Emissions}

The emission data of aerosol mass for the components sea salt, mineral dust, BC, and POM are taken from the aerosol 
Table 1. Source strength of the emissions of gases and particulate matter.

\begin{tabular}{lccl}
\hline emission & source strength & base year(s) & reference \\
\hline $\mathrm{NH}_{3}$ (GEIA 1990) & $53.6 \mathrm{TgN} / \mathrm{yr}$ & 1990 & Bouwman et al. (1997) \\
$\mathrm{DMS}$ (marine) & $18.9 \mathrm{TgS} / \mathrm{yr}$ & - & Kettle et al. (1996) \\
$\mathrm{SO}_{2}$ (fossil fuel combustion + smelting) & $65.3 \mathrm{TgS} / \mathrm{yr}$ & 1985 & Benkovitz et al. (1994) \\
$\mathrm{SO}_{2}$ (biomass burning) & $2.5 \mathrm{TgS} / \mathrm{yr}$ & 1985 & Hao et al. (1990) \\
$\mathrm{SO}_{2}$ (non-eruptive volcanoes) & $6.7 \mathrm{TgS} / \mathrm{yr}$ & - & Spiro et al. (1992) \\
$\mathrm{SO}_{2}$ (total) & $74.5 \mathrm{TgS} / \mathrm{yr}$ & & \\
$\mathrm{BC}$ (fossil fuel, no road traffic) & $\mathrm{a}$ & 1984 & Cooke and Wilson (1996) \\
$\mathrm{BC}$ (road traffic) & $6.2 \mathrm{Tg} / \mathrm{yr}$ & 1993 & Köhler et al. (2001) \\
$\mathrm{BC}$ (biomass burning) & $2.4 \mathrm{Tg} / \mathrm{yr}$ & $1980 \mathrm{~s}$ & Cooke and Wilson (1996) \\
$\mathrm{BC}$ (total) & $5.9 \mathrm{Tg} / \mathrm{yr}$ & & \\
$\mathrm{OM}$ (fossil fuel) & $14.5 \mathrm{Tg} / \mathrm{yr}$ & & \\
$\mathrm{OM}$ (biomass burning) & $29.6 \mathrm{Tg} / \mathrm{yr}$ & 1980 & Liousse et al. (1996) \\
$\mathrm{OM}$ (natural sources) & $53.9 \mathrm{Tg} / \mathrm{yr}$ & $1980 \mathrm{~s}$ & Liousse et al. (1996) \\
$\mathrm{OM}$ (total) & $16.2 \mathrm{Tg} / \mathrm{yr}$ & 1990 & Guenther et al. (1995) \\
mineral dust $(<1 \mu \mathrm{m})$ & $99.7 \mathrm{Tg} / \mathrm{yr}$ & & \\
sea salt $(<1 \mu \mathrm{m})$ & $378.5 \mathrm{Tg} / \mathrm{yr}$ & $1980 \mathrm{~s}-1990 \mathrm{~s}$ & Ginoux et al. (2001) \\
\hline
\end{tabular}

a Non-road traffic BC emissions are estimated from the total BC emissions (Cooke and Wilson, 1996) and the BC data set for road traffic (Köhler et al., 2001).

mass module FL96 described in Sect. 2.1. Since simulation of submicron aerosols is the focus here, only the accumulation mode size range of sea salt and mineral dust is taken into account and the coarse mode is neglected. The splitting of emitted BC and POM into hydrophobic and hydrophilic fractions as well as the concept of parameterizing the aging of these compounds by an exponential decay have been adopted from the aerosol module FL96, too.

Table 1 summarizes the annual emissions of gaseous precursors and particulate matter (mass) from different sources used in ECHAM4/MADE. The majority of the emission data are representative for the 1980s. As a result of emissions changing over the years, this could cause discrepancies when comparing model data to measurements taken in the late 1990s. This will be discussed in more detail when evaluating the model results with the aid of observations (Sect. 3). Due to the lack of full $\mathrm{NO}_{\mathrm{x}}$ chemistry, $\mathrm{HNO}_{3}$ is implemented using climatological monthly 3-D means calculated by ECHAM4/CHEM (Hein et al., 2001). These prescribed fields are considered as sum of aerosol $\mathrm{NO}_{3}$ and gas phase $\mathrm{HNO}_{3}$, the gas/aerosol partitioning is calculated as described in Sect. 2.2.3.

Emission of particle number concentration $(N)$ per time corresponding to the emission of mass $(m)$ is calculated assuming source specific log-normal size distributions of the primary particles for each mode and each emitted component as follows:

$$
\left.\frac{\partial N}{\partial t}\right|_{\mathrm{em}}=\left.\frac{\partial m}{\partial t}\right|_{\mathrm{em}} \cdot \frac{6}{\rho_{p} \pi d_{g}^{3} \exp \left(\frac{9}{2}\left(\ln \sigma_{g}\right)^{2}\right)}
$$

where $\rho_{p}$ is the specific density of the emitted particle type, $d_{g}$ the median diameter and $\sigma_{g}$ the geometric standard deviation of the unimodal size distribution. For primary carbonaceous particles (BC and POM), different size distributions are used for fossil fuel combustion and biomass burning. The size distributions used are summarized in Table 2.

\subsubsection{Aerosol physics}

In the following, the basic aerosol physics covered by MADE as well as changes of the nucleation scheme applied for the use of MADE in ECHAM, will be characterized briefly. For further details we refer to Binkowski and Shankar (1995) and Ackermann et al. (1998).

For this study, the simulation of particulate matter is limited to the submicron fraction. Coarse particles are not taken into account. This reduces the computational expenses without loosing accuracy when simulating submicrometer particles, because the interaction between submicron and coarse particles is very limited due to the different source types and time scales involved. The particles do not interact with the radiation scheme yet. This greatly simplifies the evaluation of the aerosol physics, since the model dynamics are not altered. The coupling of the aerosol properties calculated by MADE to the ECHAM radiation module and the inclusion of coarse particles will be a next step in our further model development. For the present study, the particle mass concentrations calculated by the aerosol mass module FL96 described in Sect. 2.1 are considered by the radiation module of the GCM instead (Fig. 1, Feichter et al., 1997). 
Table 2. Parameters of the log-normal size distributions used for calculating the corresponding particle number concentration from the mass emitted (Eq. 3). ff = fossil fuel, bb = biomass burning, nat = natural sources. POA refers to primary organic aerosol, SOA to secondary organic aerosol. $\mathrm{d}_{g}$ specifies the geometric mean diameter of the mode, $\sigma_{g}$ the geometric standard deviation and $\mathrm{m}$ specifies the percentage of total mass emitted into each mode. Coarse modes (if present) are not taken into account.

\begin{tabular}{lccccccl}
\hline \multirow{2}{*}{ emission } & \multicolumn{3}{c}{ Aitken mode } & \multicolumn{3}{l}{ accumulation mode } & refence \\
& $\mathrm{d}_{g}(\mu \mathrm{m})$ & $\sigma_{g}$ & $\mathrm{~m}(\%)$ & $\mathrm{d}_{g}(\mu \mathrm{m})$ & $\sigma_{g}$ & $\mathrm{~m}(\%)$ & \\
\hline $\mathrm{BC}_{\mathrm{ff}}$ & 0.0201 & 2.0 & 75.0 & 0.1775 & 2.0 & 25.0 & Seinfeld and Pandis (1998) \\
$\mathrm{BC}_{\mathrm{bb}}$ & 0.01 & 1.5 & 0.01 & 0.16 & 1.7 & 95.55 & Penner et al. (1998) \\
$\mathrm{POA}_{\mathrm{ff}}$ & 0.01 & 1.7 & 2.0 & 0.09 & 2.0 & 98.0 & $-^{\mathrm{a}}$ \\
$\mathrm{SOA}_{\mathrm{ff}}$ & 0.01 & 1.7 & 1.0 & $-\mathrm{b}$ & $-^{\mathrm{b}}$ & 99.0 & $-^{\mathrm{a}}$ \\
$\mathrm{SOA}_{\text {nat }}$ & 0.01 & 1.7 & 1.0 & $-\mathrm{b}$ & $-\mathrm{b}$ & 99.0 & $-^{\mathrm{a}}$ \\
POM $_{\mathrm{bb}}$ & 0.01 & 1.5 & 0.01 & 0.16 & 1.7 & 95.55 & Penner et al. (1998) \\
mineral dust & - & - & - & 0.14 & 1.95 & 4.35 & Hess et al. (1998) \\
sea salt (small) & - & - & - & 0.06 & 2.03 & 0.2 & Hess et al. (1998) \\
sea salt (large) & - & - & - & 0.418 & 2.03 & 99.8 & Hess et al. (1998) \\
\hline
\end{tabular}

${ }^{a}$ First guess obtained from measurements near sources and in (aged) polluted urban air (Hildemann et al., 1991), resulting in reasonable good agreement with observations of particle number concentrations in regions, where emissions of organic matter are most dominant.

${ }^{\mathrm{b}}$ Condensation on pre-existing particles.

\section{Nucleation}

The nucleation of the binary system sulfuric acid and water vapor is parameterized after Vehkamäki et al. (2002). This parameterization replaces the previously used formulation of the nucleation rate by Kulmala et al. (1998). Due to its larger domain of input parameters (i.e. temperature, relative humidity, concentration of sulfuric acid) it is better suited for the needs of a global model. Napari et al. (2002) introduced a ternary nucleation parameterization, which additionally takes into account $\mathrm{NH}_{3}$. Unfortunately, this parameterization cannot be used in cases of very low or none ammonia concentrations. Thus, this parameterization does not comply with the needs of the global model system ECHAM4/MADE. All freshly nucleated sulfate particles are added to the Aitken mode assuming a wet particle diameter of $3.5 \mathrm{~nm}$. This particle size is chosen according to measurements by Weber et al. (1997). The production rate of particulate sulfate mass by nucleation is estimated consistently from the rate of new particle formation (in terms of particle number density). In case of efficient nucleation, typically all sulfuric acid vapor available is nucleated.

\section{Condensation}

In this study, the condensation of sulfuric acid vapor onto the surface of pre-existing particles is calculated considering vapor fluxes explicitly. The MADE extension SORGAM (Schell et al., 2001), which also treats condensation of organic vapors (secondary organic aerosol formation), can optionally be included, as soon as a chemistry module covering organic aerosol precursor chemistry is coupled to ECHAM4/MADE. In the MADE version applied here, the production secondary organic aerosols by condensation is considered in a simplified manner. Following Cooke et al. (1999) we estimate the amount of secondary organic aerosols to $50 \%$ of the total mass of organic aerosols emitted. We further assume, that $99 \%$ of this secondary organic aerosol mass condensates onto pre-existing particles and $1 \%$ of this mass generates aged nucleation particles (Aitken mode) by new particle formation. The accumulation mode mostly dominates the aerosol surface area. Thus we assume that the total mass of secondary organics available for condensation increases the accumulation mode mass only. The accumulation mode particle number concentration remains unchanged (see Table 2). This results in a reasonable good agreement with measurements of particle number concentration in regions, where organic matter is most dominant.

\section{Coagulation}

MADE calculates intra- and intermodal coagulation due to Brownian motion of the particles. Assuming that the size distribution remains log-normally distributed, the equations are formulated in a way, that enables computational efficient calculation of coagulation (Whitby et al., 1991). By convention, the particles formed by coagulation remain in the same mode in case of intramodal coagulation. A particle formed by intermodal coagulation is assigned to the mode of the particle with the larger diameter (i.e. accumulation mode). Changes in number concentration of the Aitken mode with time due to coagulation can result from both intra- and intermodal coagulation. In the case of the accumulation mode number concentration, intramodal coagulation is relevant only. The 3rd moment of the accumulation mode is changed by intermodal coagulation only. Intermodal coagulation results in a 
decrease of 3rd moment of the Aitken mode and an increase of the 3rd moment of the accumulation mode.

Mode merging

The submicrometer aerosol in MADE is represented by the sum of two overlapping and interacting modes. This approach allows a representation of the aerosol size distribution typically found in measurements. Due to condensation or coagulation, the modes can grow with time and may become indistinguishable after a certain period of simulation, which is not being observed in nature. Hence, an algorithm is needed, that handles the transfer of particles from the Aitken to the accumulation mode, i.e. allows particles to grow from the Aitken mode into the larger accumulation mode. This algorithm is called mode merging. To determine whether mode merging is necessary or not, the growth rates of both modes are compared to each other. The growth rates are given by the increases in 3rd moment due to nucleation and condensation in the case of the Aitken mode and by condensation and intermodal coagulation in the case of the accumulation mode. Once the growth rate of the Aitken mode exceeds that of the accumulation mode, mode merging is being performed by calculating the diameter of intersection between the Aitken and accumulation mode number distributions and transferring all Aitken mode particles larger than this diameter to the accumulation mode (Binkowski et al., 1996). To ensure numerical stability, no more than one half of the Aitken mode mass can be transferred to the accumulation mode within a single time step.

\subsubsection{Aerosol chemistry}

The aerosol chemistry treats the chemical equilibrium system of sulfate, nitrate, ammonium, and water. The aerosol chemistry module originally implemented in MADE, based on the equilibrium models MARS (Saxena et al., 1986) and SCAPE (Kim et al., 1993a,b), has been replaced by the Equilibrium Simplified Aerosol Model (EQSAM) v1.0 (Metzger et al., 2002a,b). This reduces the overall computational expenses of ECHAM4/MADE significantly. The main purpose of EQSAM is to calculate the partitioning of $\mathrm{NH}_{3}$ and $\mathrm{HNO}_{3}$ between gas phase and particles, as well as the aerosol liquid water content. The aerosol liquid water content depends on the chemical composition of the aerosol and the ambient relative humidity. Aerosol water is treated just as all other chemical components. Thus an increase in aerosol water results in an increase of the total aerosol mass. With the particle number concentration remaining constant in case of water uptake, the modal mean diameter of the corresponding aerosol mode increases. For more information on EQSAM including technical details, further features, and a comparison with results of conventional equilibrium models (e.g. ISORROPIA, Nenes et al., 1998), the reader is referred to Metzger et al. (2002a,b).
Sulfur chemistry

The sulfur chemistry implemented includes the production of sulfuric acid vapor and sulfate dissolved in cloud droplets. This chemistry scheme has been adopted from the aerosol mass module FL96 (Sect. 2.1) and was extended to explicitly take into account $\mathrm{NH}_{4}$. The liquid phase reactions depend on how much $\mathrm{SO}_{2}$ can be dissolved in cloud droplets. The solubility of $\mathrm{SO}_{2}$ depends on the pH-value, which was estimated by Feichter et al. (1996) assuming a molar ratio of sulfate to ammonium of $1 / 1$. This assumption is dispensable in ECHAM4/MADE as ammonia/ammonium is considered explicitly.

This could be achieved by extending the model to calculate the full life cycle of $\mathrm{NH}_{3}$. This includes emission from various sources at the surface using the 1990 data set from the Global Emission Inventory Activity (GEIA) (Bouwman et al., 1997) (Table 1), consideration of dry and wet deposition of $\mathrm{NH}_{3}$ and the gas/aerosol partitioning between $\mathrm{NH}_{3}$ and $\mathrm{NH}_{4}$.

\subsubsection{Dry deposition}

The basic concept of calculating the amount of particles removed by dry deposition per time step has been implemented in analogy to the aerosol mass module FL96 (Sect. 2.1). As a further development of FL96, the dry deposition velocities are not prescribed, but calculated for the 0th and 3rd moment of each mode from current meteorological conditions and the actual aerosol size distribution. The deposition velocity $v_{d, k}$ of the $k$ th moment is given by:

$$
v_{d, k}=\frac{1}{r_{a}+r_{b, k}+r_{a} r_{b, k} v_{s, k}}+v_{s, k}
$$

(Slinn and Slinn, 1980), where $r_{a}$ is the aerodynamic resistance, $r_{b, k}$ the quasi-laminar layer resistance and $v_{s, k}$ the sedimentation velocity. The aerodynamic resistance is calculated following Ganzeveld and Lelieveld (1995) from the roughness length $z_{0}$ and the boundary layer stability calculated by ECHAM

$r_{a}=\frac{1}{u_{*} \kappa}\left[\ln \left(\frac{z}{z_{0}}\right)-\Phi\left(\frac{z}{L}\right)\right]$

where $u_{*}$ is the friction velocity, $\kappa$ the von-Karmann constant $(=0.4), z$ the reference height (i.e. height of the middle of the lowest model layer), $\Phi$ is a dimensionless stability term, and $L$ the Monin-Obukhov-length. Following the concepts of the aerosol mass module FL96, the dry deposition of the gas phase species $\mathrm{NH}_{3}, \mathrm{H}_{2} \mathrm{SO}_{4}, \mathrm{SO}_{2}$, DMS is calculated using prescribed dry deposition velocities (Table 3 ).

\subsubsection{Wet deposition and clouds}

The removal of particulate matter and gaseous species is calculated from the GCM's precipitation formation rate following the basic strategy used in the aerosol mass module FL96 
Table 3. Dry deposition velocities in ECHAM4/MADE. Three deposition velocities are given for $\mathrm{SO}_{2}$ : lowest deposition velocities refer to not melting snow (land) or sea ice (sea), medium refer to melting sea ice (sea) or dry/frozen surface (land), highest refer to sea (ice free) or melting snow/wet surface (land).

\begin{tabular}{lccl}
\hline species & land & sea & reference \\
\hline $\mathrm{NH}_{3}(\mathrm{~g})$ & $1.0 \mathrm{~cm} / \mathrm{s}$ & - & Dentener (1993) \\
$\mathrm{H}_{2} \mathrm{SO}_{4}(\mathrm{~g})$ & $0.2 \mathrm{~cm} / \mathrm{s}$ & $0.2 \mathrm{~cm} / \mathrm{s}$ & Wilson et al. (2001) \\
$\mathrm{SO}_{2}(\mathrm{~g})$ & $0.1 ; 0.2 ; 0.8 \mathrm{~cm} / \mathrm{s}$ & $0.1 ; 0.8 ; 1.0 \mathrm{~cm} / \mathrm{s}$ & Feichter et al. (1996) \\
$\mathrm{DMS}(\mathrm{g})$ & - & - & Feichter et al. (1996) \\
particle number & $v_{d, 0}$ & $v_{d, 0}$ & Ackermann et al. (1998) \\
particle mass & $v_{d, 3}$ & $v_{d, 3}$ & Ackermann et al. (1998) \\
\hline
\end{tabular}

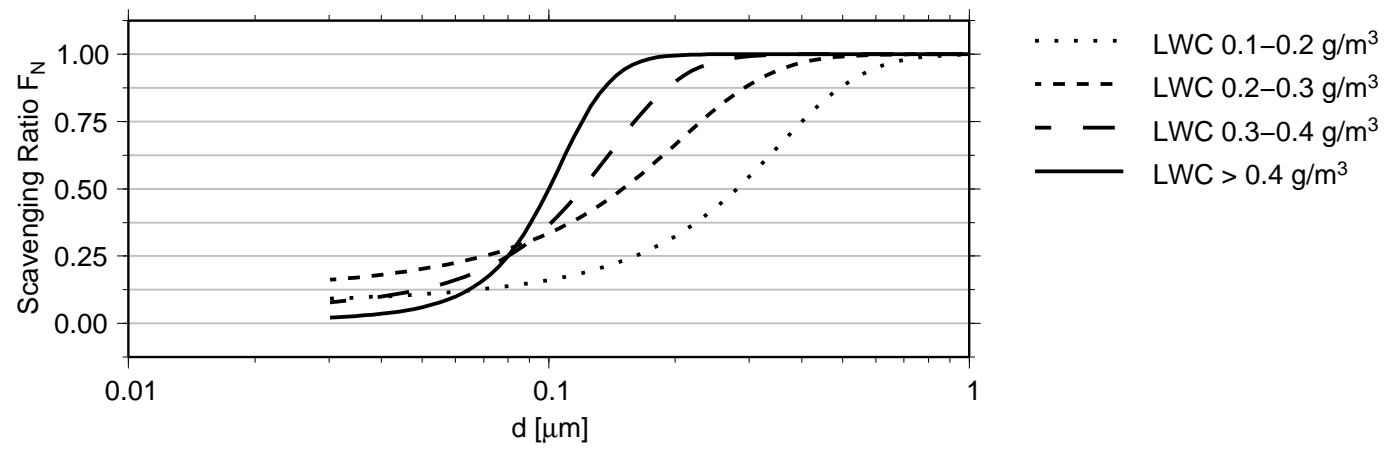

Fig. 3. Scavenging ratio $F_{N}$ versus particle diameter d for four different regimes of the cloud liquid water content (LWC) (Henning et al., 2002).

(Sect. 2.1). The wet deposition of particulate matter is treated separately for warm (liquid water) and cold (ice) clouds and for Aitken mode and accumulation mode particles. The relevant processes considered are in-cloud scavenging, belowcloud scavenging, and re-evaporation. In contrast to the aerosol mass module FL96, scavenging coefficients are not prescribed in MADE but calculated from cloud microphysical properties and the aerosol size distribution.

Due to the large uncertainties related to aerosol alteration in clouds, we do not consider any aerosol dynamical processes of the interstitial aerosol, i.e. all aerosol dynamics such as coagulation or condensation are only calculated for the cloud free part of the grid box. We only consider the interaction of aerosols with cloud particles.

\section{Warm clouds}

The model considers impact scavenging of Aitken mode particles due to Brownian diffusion. The cloud droplet size distribution required to calculate the scavenging rate is assumed to be log-normal with $\sigma=1.2$ (Binkowski and Roselle, 2003). Cloud droplet number concentration and cloud liquid water content are calculated by the cloud module and are used to derive the cloud droplet size distribution.

Accumulation mode particles are subject to activation scavenging, based on size-resolved measurements of the acti- vated particle fraction and the interstitial aerosol in cumulus and stratocumulus clouds (Henning et al., 2002). Figure 3 shows the scavenging ratio (ratio of scavenged aerosol fraction to total aerosol concentration) versus aerosol (dry) diameter calculated after an empirical fit to the measurement data for different regimes of the cloud liquid water content (LWC). In order to calculate the modal scavenging factors for accumulation mode number $\left(F_{0, l}\right)$ and mass $\left(F_{3, l}\right)$, the scavenging ratio $F_{N}$ has to be integrated over the size distribution of the accumulation mode:

$$
\begin{aligned}
& F_{0, l}=\frac{1}{N} \int_{0}^{\infty} n(d) F_{N}(d) \mathrm{d} d \\
& F_{3, l}=\frac{1}{V} \int_{0}^{\infty} \frac{\pi}{6} d^{3} n(d) F_{N}(d) \mathrm{d} d
\end{aligned}
$$

As for Aitken mode particles, the scavenged fraction of aerosol number and mass can be removed from the atmosphere by subsequent formation of precipitation due to autoconversion and accrenscence of cloud water to rain in the cloud covered fraction of the grid cell. All chemical aerosol components but hydrophobic $\mathrm{BC}\left(\mathrm{BC}_{\mathrm{phob}}\right)$, hydrophobic POM ( $\left.\mathrm{POM}_{\mathrm{phob}}\right)$ and mineral dust are scavenged applying $F_{3, l}$ (Eq. 6). Hydrophobic BC and POM are not scavenged. It is assumed, that these particles cannot be acti- 
vated to cloud droplets. In analogy to Lohmann (2002), we assume $90 \%$ of mineral dust to be hydrophobic and that the remaining $10 \%$ can be scavenged only. To take into account the hydrophobic mass fraction, the scavenging factor of accumulation mode number concentration $F_{0, l}$ is adjusted as follows:

$$
F_{0, l}^{*}=F_{0, l} \cdot\left(1-\frac{M_{3}\left(\mathrm{BC}_{\mathrm{phob}}\right)+M_{3}\left(\mathrm{POM}_{\mathrm{phob}}\right)+0.9 \cdot M_{3}(\mathrm{DUST})}{M_{3}(\text { total })}\right)
$$

Finally, the number of activated aerosol particles is obtained by multiplying the accumulation mode number concentration by the scavenging ratio $F_{0, l}^{*}$. The remaining interstitial particles within the cloud are assumed to be unchanged by wet deposition.

\section{Cold clouds}

The model takes into account activation scavenging of accumulation mode aerosol by ice clouds. Aitken mode particles are not subject to activation scavenging, since such small particles are poor freezing nuclei (e.g. Koop et al., 2000). Impact scavenging of aerosol by ice particles is neglected here, since this process is very inefficient due to the small number concentrations of ice crystals. The scavenging of accumulation mode mass by ice clouds is calculated in analogy to Lohmann et al. (1999). Since the current knowledge on heterogeneous ice nucleation is poor, we consider homogeneous nucleation as the major ice formation mechanism. Therefore, only hydrophilic particles are assumed to be scavenged. In contrast to Lohmann et al. (1999), a scavenging efficiency of 5\% is assumed instead of $10 \%$, which improves the simulated mass concentrations in accordance to measurement data in the tropopause region (Hendricks et al., 2004). To estimate the corresponding scavenging of accumulation mode number concentration from the scavenged mass fraction, it is assumed that only the largest particles of the log-normal size distribution are scavenged since the larger aerosol particles are probably the most efficient freezing nuclei (e.g. Koop et al., 2000).

\section{Below-cloud scavenging}

Between cloud layers and below the lowest clouds, trace gases and hydrophilic particulate matter can be collected by falling rain or snow and subsequently removed from the atmosphere. The parameterization of below-cloud scavenging applied here follows the approach of Berge (1993).

\section{Evaporation}

Cloud droplets or ice crystals that have not been removed by precipitation evaporate once the cloud dissolves. Consequently, previously scavenged trace gases and aerosol particles are released. It is assumed, that all of the released aerosols are in the size range of the accumulation mode, as only accumulation mode particles are activated when the cloud forms and Aitken particles incorporated into clouds by impact scavenging are released within cloud residues containing also accumulation mode particles. Thus, all Aitken mode particles, which have undergone impact-scavenging and which have not been removed by precipitation, are assumed to become accumulation mode particles once the cloud evaporates. Hence Aitken mode mass is added to the corresponding accumulation mode mass tracer. Particle number concentration of scavenged Aitken mode particles is not transfered to the accumulation mode and will be discarded (Binkowski, 1999).

\section{Comparison with observations}

An evaluation of the results obtained from a first multiannual integration with ECHAM4/MADE is required to evaluate the ability of the new model system to reproduce observed aerosol distributions.

Principle difficulties arise when comparing GCM results with observations. First, due to the coarse spatial resolution of the model, highly variable species such as particle number concentration measured by individual ground based stations can hardly be compared to simulated concentrations averaged over model grid cells representing a domain of thousands of square kilometers. The basic strategy followed here to circumvent this problem is to average station data within a larger domain. Second, since ECHAM is designed as a climate model (see Sects. 2.1 and 2.2.2 for details of the model setup and boundary conditions used), it is not capable to simulate real episodes. Thus, measurements taken at a specific period of time cannot be compared to the model results directly, but based on climatological means only. Therefore, only long-term data covering several weeks or months are applied here for intercomparison with model data.

\subsection{Global aerosol distribution}

Before comparing the model results to observations, we will discuss the most basic features of the simulated global aerosol distributions. Figure 4 depicts the global distributions of column mass concentrations for the aerosol components sulfate, ammonium, nitrate, aerosol water, black carbon, and particulate organic matter. Climatological (10 years) annual means of the sum of Aiken mode and accumulation mode mass concentrations simulated by ECHAM4/MADE are presented. The geographical distributions are clearly characterized by the regions of high anthropogenic emissions, especially in North America, Europe, and Southeast Asia as well as the major biomass burning regions in Africa and South America. In the following (Sect. 3.2), the simulated mass concentrations will be evaluated by comparisons to observational data. A detailed discussion of the global distributions simulated is beyond the scope of this 

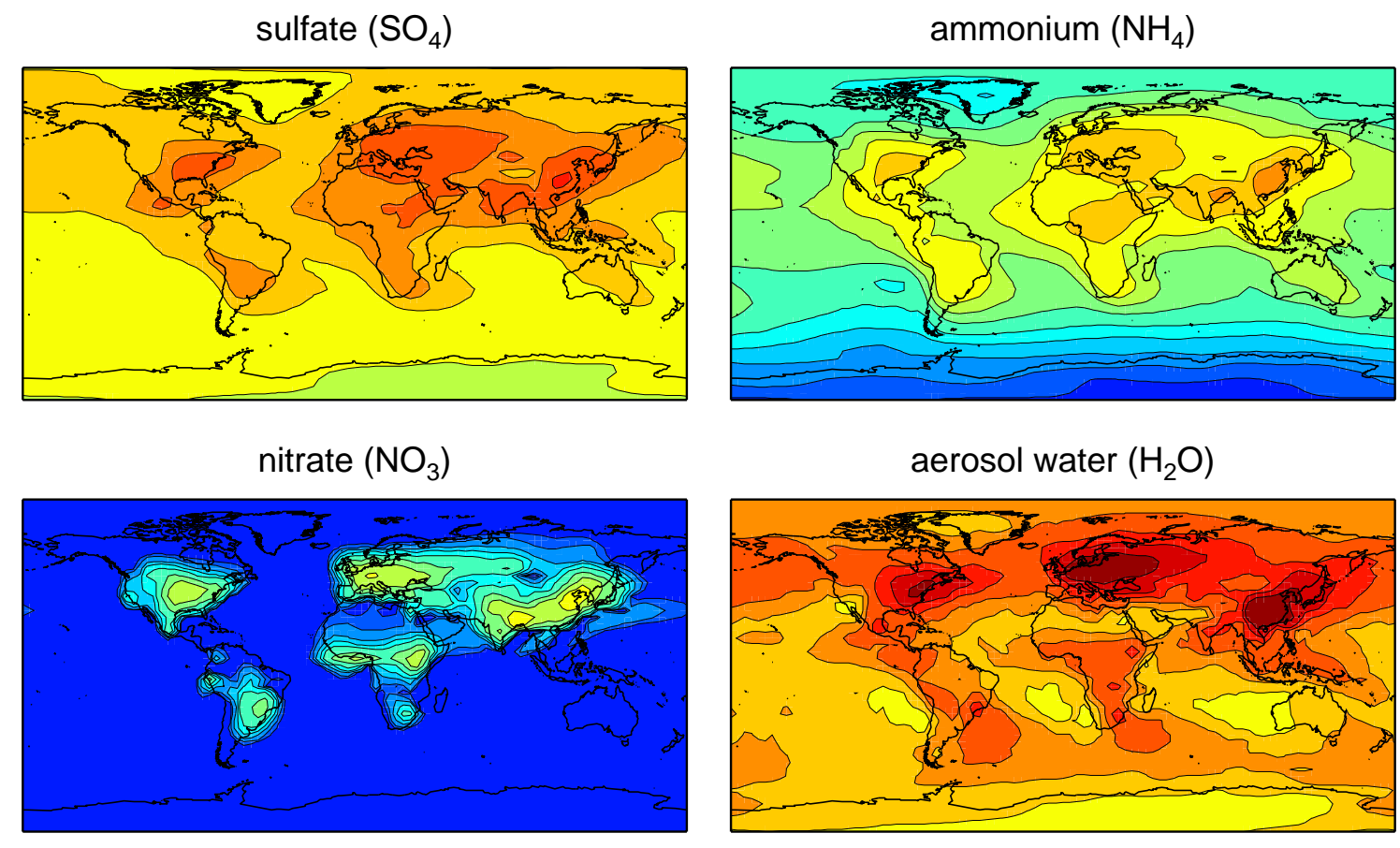

black carbon $(\mathrm{BC})$

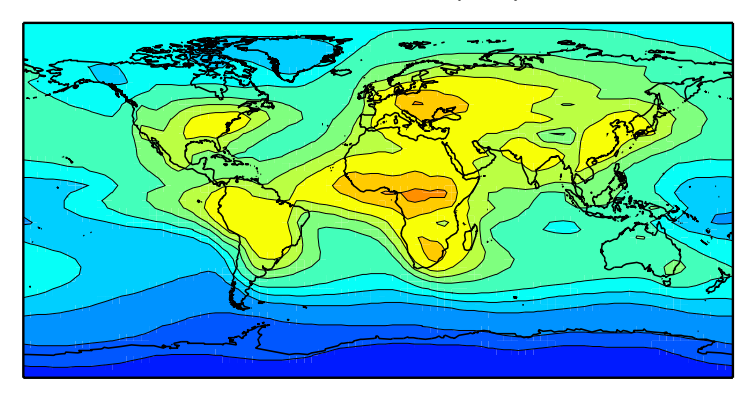

particulate organic matter (POM)
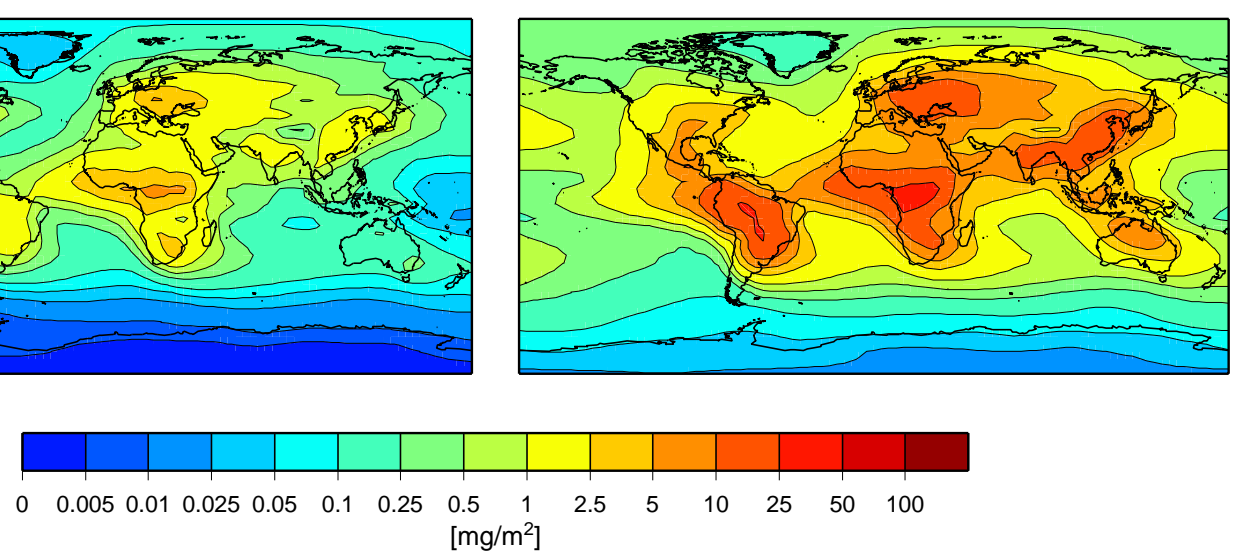

Fig. 4. Climatological annual means of the column mass concentrations $\left(\mathrm{mg} / \mathrm{m}^{2}\right)$ of the aerosol components $\mathrm{SO}_{4}, \mathrm{NH}_{4}, \mathrm{NO}_{3}, \mathrm{H}_{2} \mathrm{O}, \mathrm{BC}$ and POM in fine particles (sum of Aitken and accumulation mode) obtained from a 10-year integration with the model system ECHAM4/MADE.

paper since it is intended to focus on the description and evaluation of the new model system. A detailed analysis of the properties of the global submicrometer aerosol simulated with ECHAM4/MADE, an interpretation of the results, and an examination of the role of aerosol dynamics on the global scale will be provided by a separate paper (Part II: Results from a first multiannual integration).

\section{Comparison with FL96}

In the model configuration used for this study, the mass based aerosol module FL96 and the aerosol dynamics module MADE use the same emission inventories for aerosol mass. The meteorological conditions such as temperature, relative humidity, wind fields, and clouds are identical for both aerosol modules. This allows a comparison of the aerosol mass simulated by MADE and FL96 for components, which are largely contained in submicrometer particles (i.e. $\mathrm{SO}_{4}, \mathrm{BC}$, and $\mathrm{POM}$ ). The climatological annual averages of the geographical distribution of the near surface mass concentrations of these components as well as the corresponding zonally averaged latitude-height cross-sections are almost identical in a qualitative manner. Nevertheless, the zonal averages of the $\mathrm{SO}_{4}$ concentrations calculated by MADE are about $10 \%$ to $20 \%$ higher than that by FL96 in the lower troposphere. This discrepancy is even larger in the 

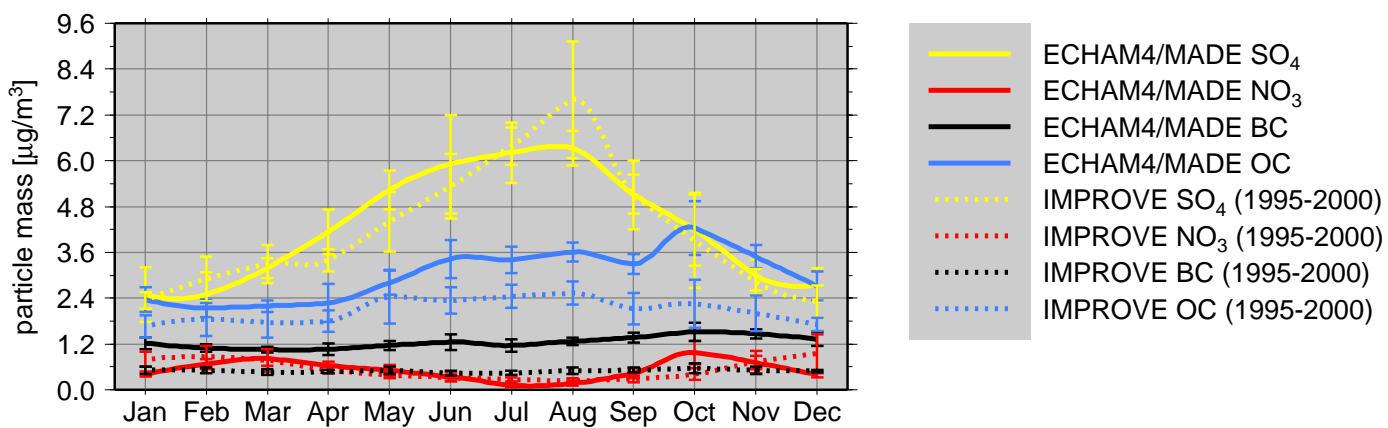

Fig. 5. Climatological seasonal cycle of observed and modeled near surface mass concentrations of the aerosol components $\mathrm{SO}_{4}, \mathrm{NO}_{3}$, $\mathrm{BC}$, and $\mathrm{OC}$ in fine particles $\left(\mathrm{PM}_{2.5}\right)$, averaged over the south-eastern part of the USA. The error bars denote the standard deviation of the individual monthly means to the climatological average.

upper troposphere. Nevertheless, the mass concentrations of $\mathrm{SO}_{4}$ in the upper troposphere calculated by both modules are about two orders of magnitude smaller than that in the lower troposphere. In case of POM, the mass concentrations calculated by MADE are about 20\% higher than that of FL96 in the regions with significant POM mass concentrations (about $50^{\circ} \mathrm{S}-60^{\circ} \mathrm{N}$ ). In contrast to $\mathrm{SO}_{4}$, these differences do not vary much with height. For BC, the differences between FL96 and MADE are less distinctive. Whereas MADE shows lower $\mathrm{BC}$ concentrations in the northern hemisphere (up to about 20\%), MADE shows higher BC concentrations in the southern hemisphere (about 10\%). Nevertheless, the total burdens of these aerosol components simulated by both modules are quite similar. For $\mathrm{SO}_{4}$, MADE calculates $2.25 \mathrm{Tg}$ versus $2.18 \mathrm{Tg}$ (FL96), for BC $0.26 \mathrm{Tg}$ (MADE) versus $0.23 \mathrm{Tg}$ (FL96), and for POM 1.77 Tg (MADE) versus $1.46 \mathrm{Tg}$ (FL96).

Thus, the calculation of aerosol dynamical processes seems to be less essential for the simulation of the total aerosol mass than for the simulation of particle number concentration and size-distribution. This will be discussed by the separate paper mentioned above in more detail.

\subsection{Near surface mass concentrations}

\subsubsection{United States}

To evaluate the modeled near surface mass concentrations, we use observational data taken within the Interagency Monitoring of Protected Visual Environments (IMPROVE), which is a cooperative monitoring program of the United States Environmental Protection Agency (EPA), federal land management agencies, and state air agencies (Malm et al., 2000). Besides other tasks, aerosols (mass) and visibility are measured on a regularly basis by many stations, located in national parks, national wildlife refuges, and other protected areas all over the United States. Measurement data of several years are available (IMPROVE: http://vista.cira. colostate.edu/improve/).
An intercomparison of IMPROVE data with ECHAM4/MADE is performed based on climatological monthly means. The model data are averaged over all 10 model years. The IMPROVE data shown here represent averages of the years 1995 to 2000 . In order to avoid any improper weighting of areas with different densities of measurement sites, all data from sites located within the same ECHAM T30 grid cell are averaged before any further processing. The measurements were taken near the surface. Thus, the model results calculated for the lowest model layer are used for the intercomparison. In order to obtain a quantitative measure for the differences between model and observations, the normalized mean error (NME) is calculated as follows:

$\mathrm{NME}=\frac{\sum_{\mathrm{i}=1}^{\mathrm{N}} \mid \text { model }_{\mathrm{i}}-\text { observation }_{\mathrm{i}} \mid}{\sum_{\mathrm{i}=1}^{\mathrm{N}} \text { observation }_{\mathrm{i}}} \cdot 100 \%$

In case of the seasonal cycles, model $_{\mathrm{i}}$ is the climatological model data for month $\mathrm{i}$, observation $\mathrm{i}_{\mathrm{i}}$ the corresponding measurement data and $\mathrm{N}$ is the number of months $(=12)$. When calculating the normalized mean error of the geographical distribution, i loops over all T30 grid cells with observational data available and $\mathrm{N}$ is the total number of grid cells with measurement data.

Seasonal cycle

Figure 5 shows the seasonal cycle of aerosol components in fine particles $\left(\mathrm{PM}_{2.5}\right.$, i.e. $\left.\mathrm{d}<2.5 \mu \mathrm{m}\right)$, measured by the IMPROVE network and calculated by ECHAM4/MADE. The mass concentrations of the aerosol components compared are dominated by fine particles in the size-range of the Aitken and the accumulation mode, which allows a comparison of the measured $\mathrm{PM}_{2.5}$ concentrations with the model, which currently neglects a coarse mode. All available values have been averaged over the south-eastern part of the USA $\left(\approx 77^{\circ}\right.$ $96^{\circ} \mathrm{W}, 30^{\circ}-41^{\circ} \mathrm{N}$ ). This region of North America is characterized by high anthropogenic emissions of $\mathrm{SO}_{2}, \mathrm{BC}$, and OC. 
Both, model and observations show maximum sulfate concentrations in summer and minimum concentrations in winter. There is no systematic under- or overestimation by the model. The averaged normalized mean error of the modeled sulfate is $10 \%$. The seasonal cycle of nitrate is in opposite phase with sulfate, showing a maximum in winter and a minimum in summer. ECHAM4/MADE reproduces the summer minimum only. The winter maximum of the observed values is not shown by the model. The NME for nitrate is $39 \%$. During most of the year, $\mathrm{NO}_{3}$ is underestimated by the model with respect to the measurements. This discrepancy in the seasonal cycle of $\mathrm{NO}_{3}$ could be related to the use of a $\mathrm{HNO}_{3}$ climatology, which cannot respond to current meteorological conditions. Both the model and observed BC concentrations show almost no seasonal cycle. However, ECHAM4/MADE shows much higher BC concentrations than the IMPROVE measurements. On average, the model results are 2-3 times higher than the corresponding observations. The NME amounts to $143 \%$. This large overestimation by the model can be, at least partially, explained by the locations of the measurement sites. While all IMPROVE stations are located in remote areas such as national parks or wildlife refuges, the large ECHAM T30 grid cells also contain the emissions of the urban areas and different kinds of traffic. Particulate $\mathrm{SO}_{4}$ and $\mathrm{NO}_{3}$ are secondary aerosols. The time needed to transform precursors such as $\mathrm{SO}_{2}$ or $\mathrm{NO}_{\mathrm{x}}$ from gas to particle phase allows transport away from the sources, resulting in a geographical distribution following the pattern of the emissions less distinctive than primary particles such as BC. Thus, it can be assumed, that the background values of the IMPROVE network are more representative for the secondary aerosols than for the primary $\mathrm{BC}$ when considering the large domains covered by a ECHAM T30 grid cell. Another important reason for the overestimation of BC by the model might be the emission data used. Currently, global BC-emissions by Cooke and Wilson (1996), representative for the year 1984, are used. The corresponding emission rates are about $40 \%$ higher compared to the more recent emission data set by Bond et al. (2004), which represent the year 1996. Similar to BC, OC shows no distinct seasonal cycle in the observations. On average, the normalized mean error of OC is $38 \%$. The modeled OC mass concentrations are systematically higher than the observations. As in the case of $\mathrm{BC}$, the more recent emission data for $\mathrm{OC}$ from Bond et al. (2004) show a lower annual source strength than the OC emission data currently used. Thus, lower OC concentrations are to be expected when updating the emission data.

\section{Geographical distribution}

The annual mean geographical distributions of the aerosol components $\mathrm{SO}_{4}, \mathrm{NO}_{3}, \mathrm{BC}$, and $\mathrm{OC}$ derived from the IMPROVE measurements and the model simulation are depicted by Fig. 6. Care has to be taken when interpreting regions with no measurement sites. These gaps have been filled by the gridding and interpolation algorithms of the plot software. Thus, the figure includes white crosses to mark the measurement sites with observational data available.

Both model and observations show a distinctive west-east gradient in the geographical distributions of the $\mathrm{SO}_{4}$ mass with high concentrations found in the eastern part of the United States and low values in the western part. A minor difference between model and observations is the deviation in the exact location of the region with maximum sulfate concentrations in the eastern United States. According to the measurements, the maximum is located about $500-800 \mathrm{~km}$ farther north-easterly in the model. However, running at T30 resolution (Sect. 2.1), this distance equals 1-2 model grid cells only. The normalized mean error for sulfate is $25 \%$.

The maximum nitrate concentrations shown by the model as well as by the observations are about $1 \mu \mathrm{g} / \mathrm{m}^{3}$. Similar to sulfate, the region of maximum nitrate in the eastern United States is shifted in the model 1-2 T30 grid cells farther northeasterly. A second maximum located in the Los Angles basin of California is not reproduced by ECHAM4/MADE. Overall, nitrate concentrations are underestimated by the model with respect to the measurements (NME for $\mathrm{NO}_{3}$ is $66 \%$ ).

Since a direct intercomparison of the geographical distribution of BC is difficult due to the lower values observed, the measurement data have been multiplied by a factor of 3 (marked as " $\times 3$ " in Fig. 6) to allow for a better comparison of the geographical patterns with the model data (see "seasonal cycle" in the previous section). Similar to $\mathrm{NO}_{3}$, $\mathrm{BC}$ shows increased concentrations within a region of the eastern United States and within a second region of smaller extent in California. These patterns are reproduced by the model. In addition, the observed geographical BC distribution shows an isolated maximum over Montana, which is not reproduced by the model. This maximum is a result of a single heavy forest fire event in summer 2000. Such single events cannot be reproduced by the model running in quasiequilibrium mode using the same emission data every year. As already obvious from the comparison of the seasonal cycles, BC is overestimated by the model, resulting in a NME of $135 \%$ (see "seasonal cycle" in the previous section).

The patterns of the geographical OC distributions mostly follow those of the BC distribution. The maximum OC concentrations measured and calculated by the model are both about $3 \mu \mathrm{g} / \mathrm{m}^{3}$, but the modeled areas of high OC concentrations have a larger extent than shown by the observations. As in the BC data, also OC observations show an isolated maximum over Montana, which is likely produced by the heavy forest fires in summer 2000. In contrast, the model which does not include such single events in the emission data, shows minimum OC concentrations in this region. With regard to the overall representation of $\mathrm{BC}$ and $\mathrm{OC}$ by the model, the comparison shows that the agreement between model and measurements is much better for $\mathrm{OC}$ than for $\mathrm{BC}$. The NME amounts to $47 \%$ in the case of OC. 
IMPROVE 1995-2000
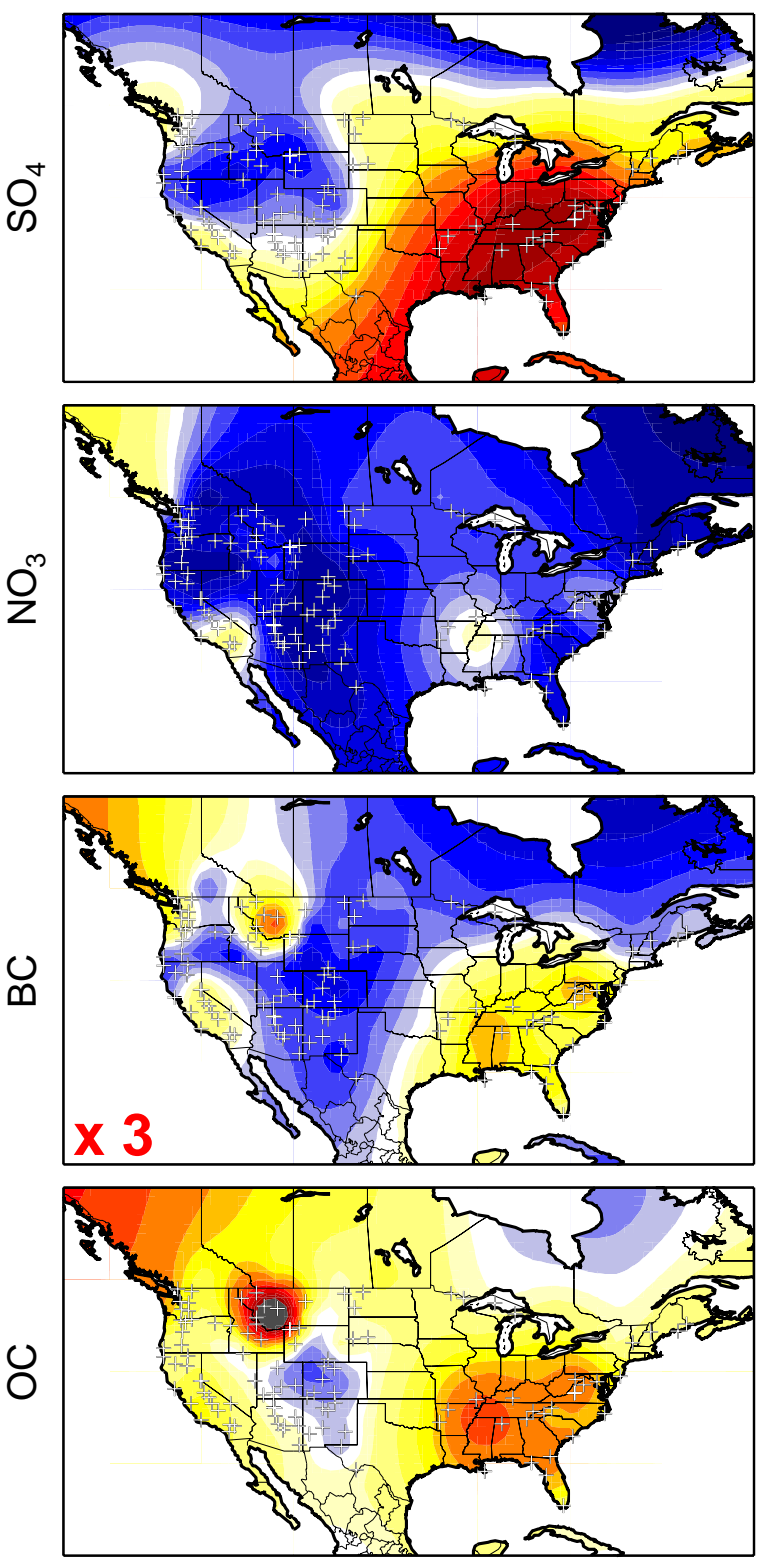

ECHAM4/MADE
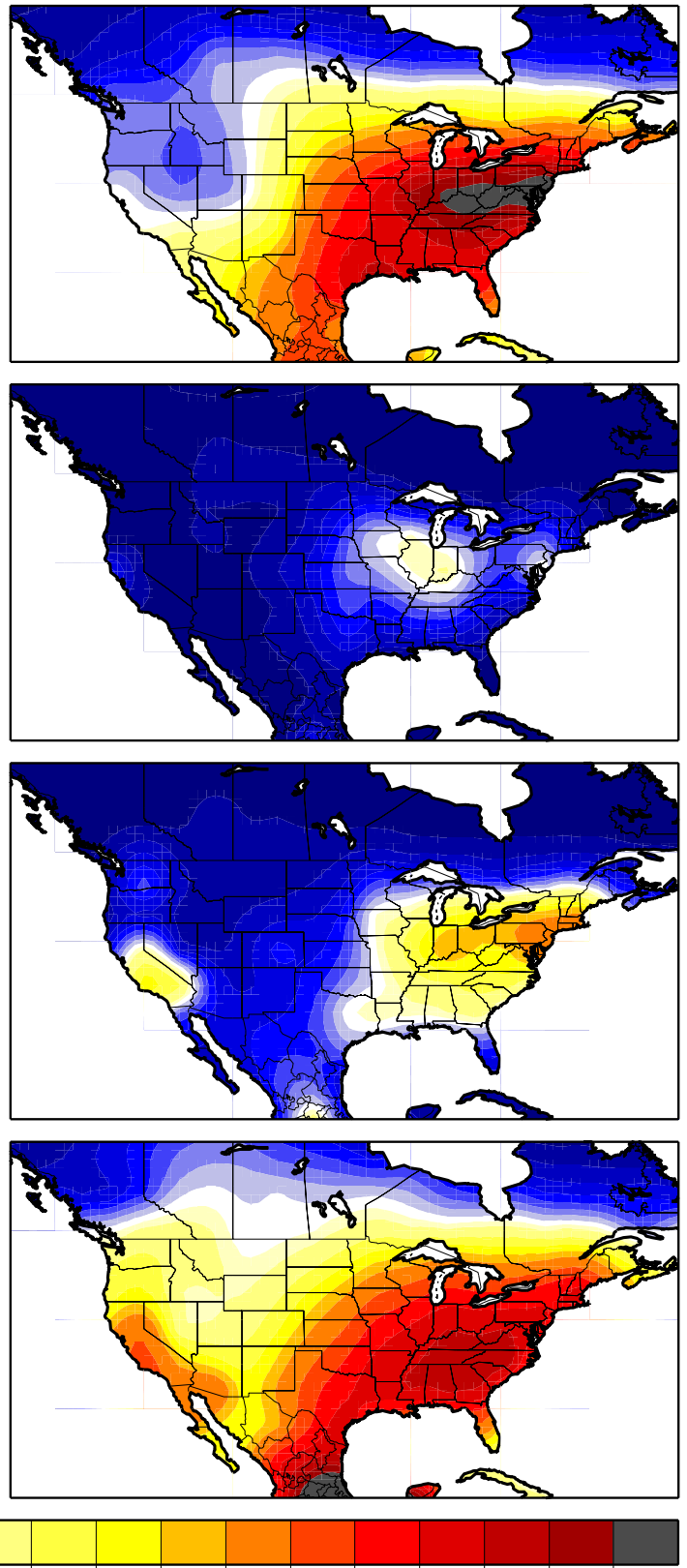

$\begin{array}{lllllllllllllllllllll}0 & 0.1 & 0.2 & 0.3 & 0.4 & 0.5 & 0.6 & 0.7 & 0.8 & 0.9 & 1 & 1.25 & 1.5 & 1.75 & 2 & 2.5 & 3 & 3.5 & 4 & 4.5 & 5\end{array}$ $\mu \mathrm{g} / \mathrm{m}^{3}$

Fig. 6. Climatological annual means of the near surface mass concentrations of $\mathrm{SO}_{4}, \mathrm{NO}_{3}$, $\mathrm{BC}$, and $\mathrm{OC}$ in fine particles $\left(\mathrm{PM}_{2.5}\right)$ obtained from measurements of the IMPROVE network (left) and from model results of ECHAM4/MADE (right). The measured BC concentrations have been multiplied by 3 (" $\times 3$ "). The white crosses denote the locations of the measurement sites.

\subsubsection{Europe}

We also compared the model results to long-term measurements (1995-2000) from stations of the Co-operative Programme for Monitoring and Evaluation of the Long-Range Transmissions of Air Pollutants in Europe (EMEP) (EMEP,
2003) measuring $\mathrm{PM}_{2.5}$ mass concentrations of $\mathrm{SO}_{4}, \mathrm{NH}_{4}$, and $\mathrm{NO}_{3}$. In analogy to the comparison with IMPROVE measurements (Sect. 3.2.1 and Fig. 5), we averaged the data available over the whole region "Europe" $\left(9^{\circ} \mathrm{W}-32^{\circ} \mathrm{O}\right.$, $37^{\circ} \mathrm{N}-71^{\circ} \mathrm{N}$ ) to smooth effects of local influence on individual measurement sites before comparing the seasonal cycle 

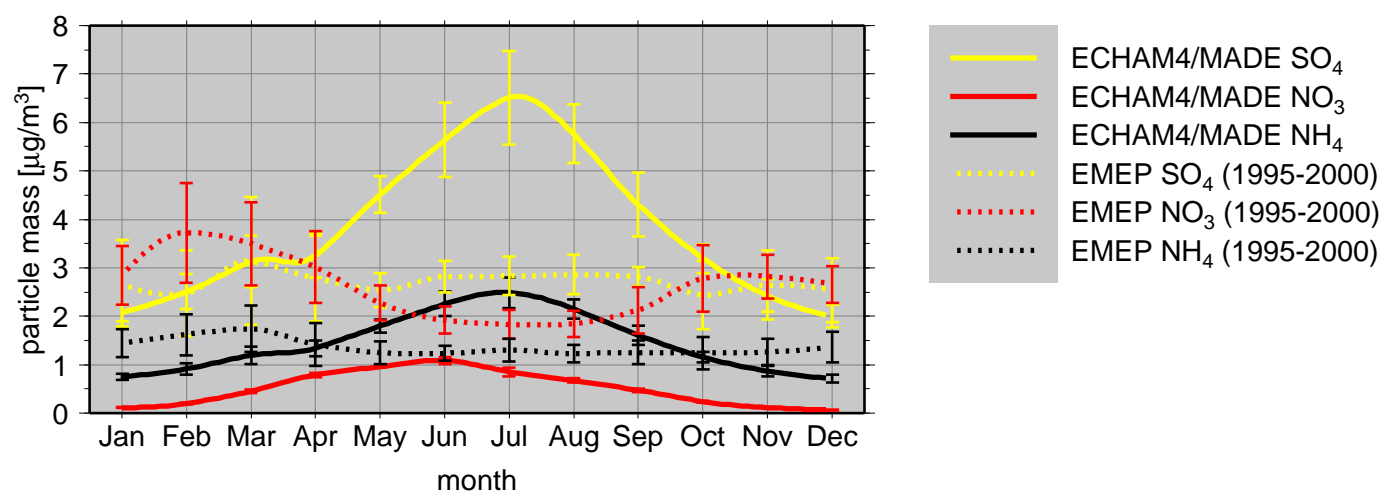

Fig. 7. Climatological seasonal cycle of observed and modeled near surface mass concentrations of the aerosol components $\mathrm{SO}_{4}, \mathrm{NO}_{3}$, and $\mathrm{NH}_{4}$ in fine particles $\left(\mathrm{PM}_{2.5}\right)$, averaged over Europe. The error bars denote the standard deviation of the individual monthly means to the climatological average.

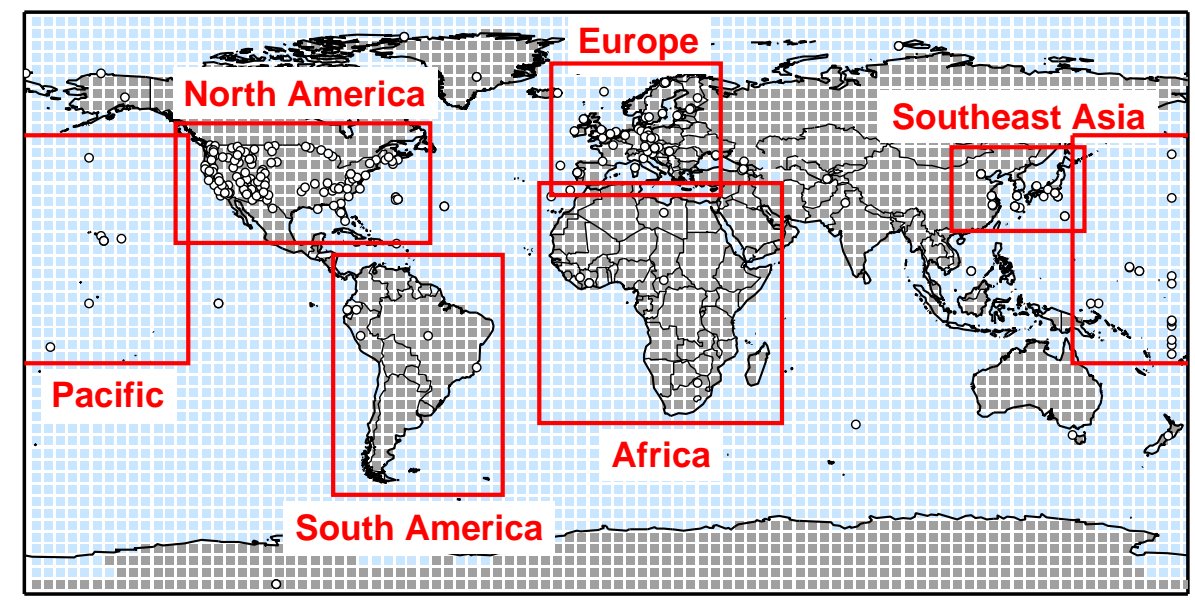

Fig. 8. Location and extent of the regions used for intercomparison of modeled and observed near surface BC mass concentrations. The white circles denote the positions of the measurement sites.

to the model data. Again, only model grid cells with observational data available are used to calculate the seasonal cycles. This comparison (Fig. 7) shows that ECHAM4/MADE is capable of reproducing the measured near surface mass concentrations of the aerosol components investigated $\left(\mathrm{SO}_{4}\right.$, $\mathrm{NH}_{4}$, and $\mathrm{NO}_{3}$ ) mostly within a factor of two. The major features of the simulated geographical distribution are similar to the measurement. However, whereas winter concentrations of $\mathrm{SO}_{4}$ of model and observations agree well, the model overestimates sulfate mass concentrations in summer by about a factor of two. This is probably caused by the emission data set used for $\mathrm{SO}_{2}$ from fossil fuel combustion, which is representative for 1985 (Benkovitz et al., 1994). In the decade from 1985 to 1995 , great success has been made reducing $\mathrm{SO}_{2}$ emissions in Europe (EEA, 2003). This results in a reduced $\mathrm{SO}_{4}$ production due to oxidation of $\mathrm{SO}_{2}$, which is most pronounced in summer when photochemical activity reaches its maximum. In the case of $\mathrm{NH}_{4}$, the model underestimates $\mathrm{NH}_{4}$ mass concentrations in winter, but results in a overestimation of $\mathrm{NH}_{4}$ in summer. Nevertheless, compared to $\mathrm{SO}_{4}$, a better quantitative agreement between model and observations is obtained. The $\mathrm{NO}_{3}$ mass concentration is underestimated by the model. Simulated $\mathrm{NO}_{3}$ mass concentrations are much too low in winter (underestimation of the $\mathrm{NO}_{3}$ mass concentration by the model up to $3.5 \mu \mathrm{g} / \mathrm{m}^{3}$ or $95 \%$ (February), respectively), whereas a much better agreement between model and measurements is obtained in summer (difference in $\mathrm{NO}_{3}$ mass concentration between model and measurements below $1 \mu \mathrm{g} / \mathrm{m}^{3}$ or smaller than $44 \%$ (June), respectively). The most obvious reason is probably the lack of a comprehensive chemistry scheme in the model system, which would be required for simulating $\mathrm{HNO}_{3}$ accurately. 

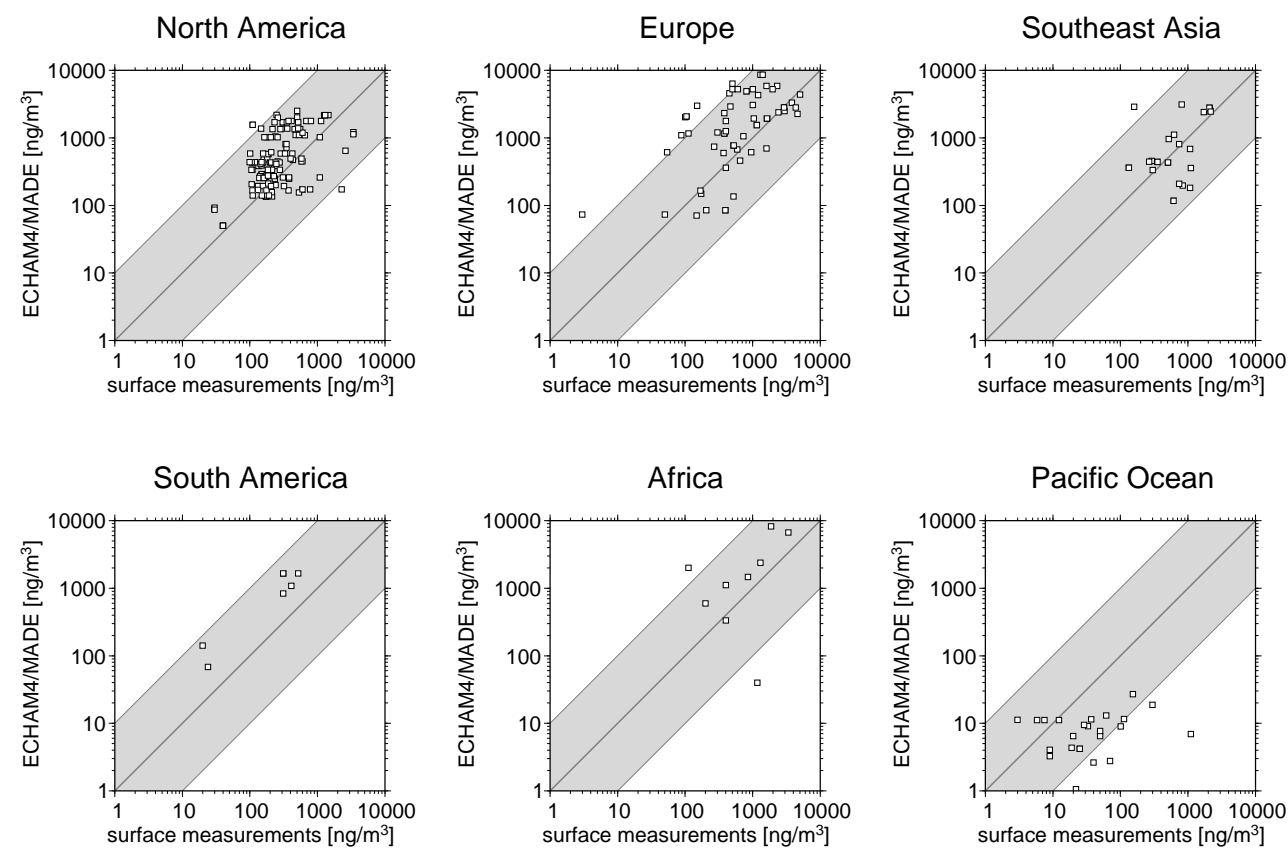

Fig. 9. Observed and modeled near surface BC mass concentrations for different measurement sites and months/seasons (white squares) divided into different geographical regions (Fig. 8). The shaded area denotes ratios of model to observation ranging from 10:1 to 1:10.

\subsubsection{Worldwide BC measurements}

The comparison of simulated near surface BC mass concentrations with IMPROVE measurements (Sect. 3.2.1) shows the largest differences between model and observations among all aerosol components, whose life cycles are explicitly simulated here. To gain further insights into the performance of ECHAM4/MADE simulating BC mass concentrations, the model data have been compared to a large number of observations performed in various geographical regions. Due to the coarse grid resolution of the model, it cannot be distinguished between kerbside, urban, rural or remote locations of the measurements sufficiently precise. Furthermore, the number of measurement sites is too low to calculate representative gridbox mean $\mathrm{BC}$ concentrations from the measurement data. Thus, we calculated large-scale averages for different geographical regions instead (Fig. 8).

We compare the near surface $\mathrm{BC}$ mass concentrations observed and modeled. Figure 9 shows the modeled BC concentrations versus observed values for the individual geographical regions. The observational data span individual months, full seasons, or annual means. The model data processed are the corresponding climatological monthly means of the grid cell containing the measurement site. The observational data are taken from compilations by Chung and Seinfeld (2002), Cooke et al. (1999), Köhler et al. (2001), Liousse et al. (1996), and Takemura et al. (2000). For the region "North America", also the data from the individual IMPROVE measurement sites (Sect. 3.2.1) are included.
In the region "North America", almost all 133 data points lie within the range 1:10 to 10:1 of modeled versus observed concentrations. The arithmetic mean of the model data is 2.5 times higher than that of the observations (factor 1.8 in the case of median concentrations). The Europe (64 stations) and Southeast Asia (29 stations) data behave similar to the North America data. On average, the ratio of modeled versus observed concentrations is 4.5 (median 1.6) for Europe and 1.7 (median 1.1) for Southeast Asia. In North America, Europe, and Southeast Asia the most important source for BC particles is fossil fuel combustion. In contrast, biomass burning plays an important role in Africa and South America. The arithmetic mean of the ratio of modeled versus observed concentrations is 3.8 (median 2.0) in Africa (9 stations) and 4.2 (median 3.2) in South America (6 stations). The 24 observational data points in the Pacific Ocean represent clean remote conditions far away from the continental anthropogenic sources. Here, the average ratio of model and observation is 0.5 (median 0.2).

In summary the $\mathrm{BC}$ mass concentrations are overestimated by the model for the continental regions and underestimated for the region Pacific Ocean. However, about $90 \%$ of all 303 observations (worldwide) are within the range 1:10 to 10:1 of modeled versus observed concentrations. The global arithmetic mean deviation amounts to 2.8 (median 1.5). The measurement sites are located in very heterogeneous environments including kerbsides as well as clean remote locations. Because of the area covered by the T30 grid cells, no exact agreement between model and observations can be expected. 

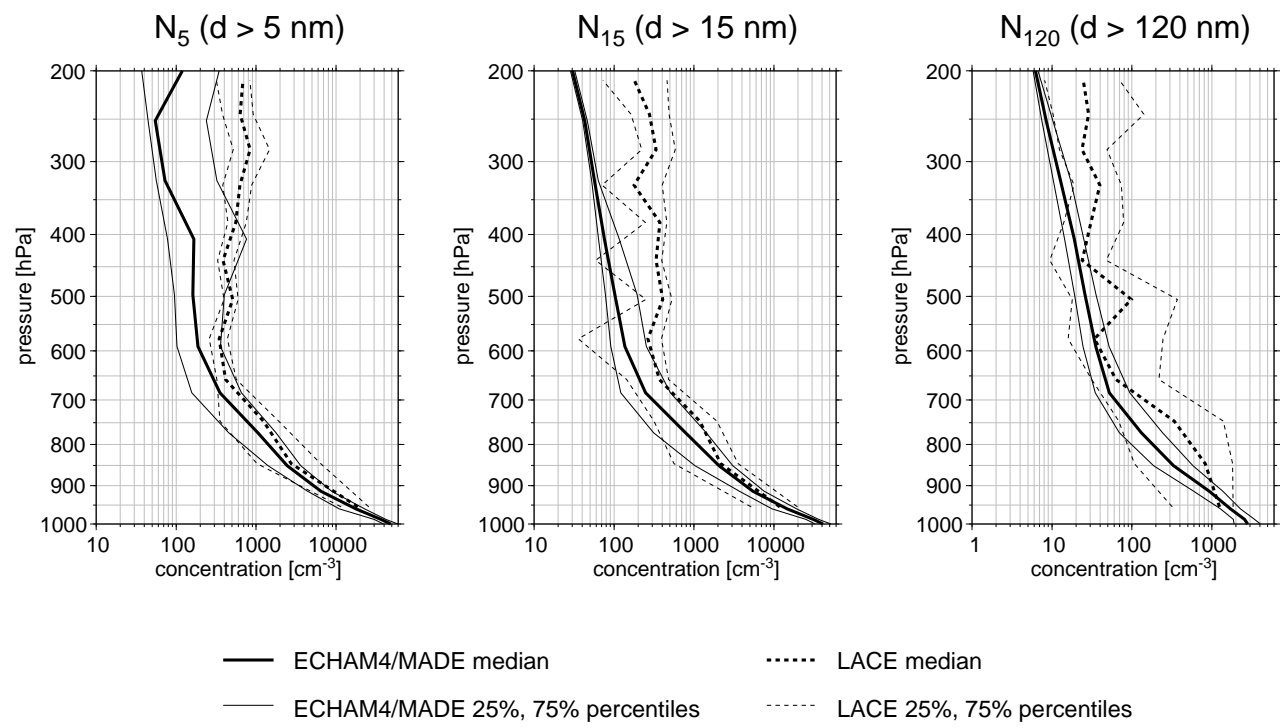

Fig. 10. Vertical profiles of aerosol number concentration (ambient, not STP conditions as in Fig. 11) in north-east Germany obtained from measurements during LACE (Petzold et al., 2002) (dashed) and calculated by ECHAM4/MADE (solid) for the 3 size classes of particles larger than $5 \mathrm{~nm}, 15 \mathrm{~nm}$, and $120 \mathrm{~nm}$.

However, this comparison shows, that ECHAM4/MADE is capable to reproduce the range of observations of $\mathrm{BC}$ mass concentrations found in polluted areas as well as in clean remote areas, which spans almost three orders of magnitude. The major geographical differences are captured correctly by the model.

\subsubsection{Particle mass concentration - conclusions}

The comparisons of measured and modeled aerosol mass concentrations show that ECHAM4/MADE is capable to reproduce the observed seasonal cycle and major features of the geographical distribution reasonably well. Quantitative differences are mostly within a factor of two with the exception of $\mathrm{BC}$ and $\mathrm{NO}_{3}$. In view of the basic difficulties and uncertainties when comparing climatological coarse resolution model output with measurements, this is a notable result. However, the comparison also shows that an updated emission data set should be adopted to reduce some of the differences found, in particular for $\mathrm{BC}$ particles. To reduce the uncertainties in particulate $\mathrm{NO}_{3}$, a comprehensive atmospheric chemistry scheme should be coupled to ECHAM4/MADE.

\subsection{Number concentration}

\subsubsection{Central Europe}

During the Lindenberg Aerosol Characterization Experiment (LACE) performed in the summer of 1998, optical and microphysical aerosol properties were measured over northeastern Germany $\left(\approx 13.5^{\circ}-14.5^{\circ} \mathrm{E}, 51.5^{\circ}-52.7^{\circ} \mathrm{N}\right)$ from two aircraft. Ten flights have been accomplished between 31 July and 12 August covering the vertical range from minimum flight altitude (150 m above ground) to tropopause height. The measurement site can be regarded as typical of polluted continental summer conditions in Central Europe. The data set used for intercomparison with ECHAM4/MADE contains the ambient (i.e. not converted to STP conditions) median particle number concentrations of particles in three different size ranges (dry diameters $\mathrm{d}>5 \mathrm{~nm}, 15 \mathrm{~nm}$, and $120 \mathrm{~nm}$, hereafter referred to as $\mathrm{N}_{5}, \mathrm{~N}_{15}$, and $\mathrm{N}_{120}$, respectively) (Petzold et al., 2002). Particles with $d>120 \mathrm{~nm}$ roughly meet the accumulation mode, $\mathrm{N}_{15}$ is dominated by Aitken mode particles and $\mathrm{N}_{5}$ includes fresh ultrafine nuclei additionally. Figure 10 presents a comparison of model data with these measurements. The variability is given by the corresponding 25\%- and 75\%-percentiles. The measurements were taken under cloud free conditions. Thus, model data with a cloud fraction of the corresponding grid cell above $10 \%$ were not taken into account. Model data from August of each year simulated were used. The percentiles shown in Fig. 10 for the model data were calculated from $12 \mathrm{~h}$ means of the modeled number concentration.

The median of the modeled particle number concentration $\mathrm{N}_{5}$ stays within the measured variability in the altitude range from the surface up to pressure levels between 700 and $650 \mathrm{hPa}$. In the boundary layer up to about $900 \mathrm{hPa}$, the modeled variability is much less than observed. This indicates, that the near surface particle number concentrations are clearly dominated by the emissions of primary particles, which remain constant during the respective month. In the free troposphere and above, $\mathrm{N}_{5}$ is systematically smaller compared to the observations. Nevertheless, the modeled 
$70^{\circ} \mathrm{S}-20^{\circ} \mathrm{S}$

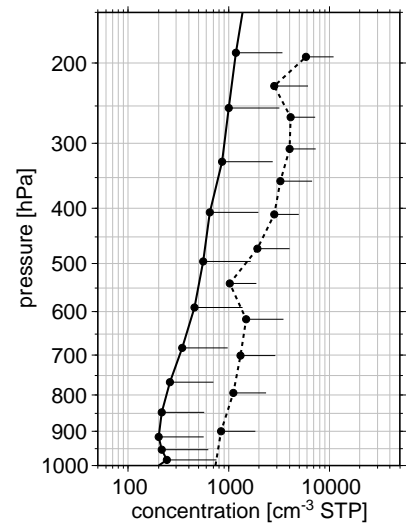

$20^{\circ} \mathrm{S}-20^{\circ} \mathrm{N}$

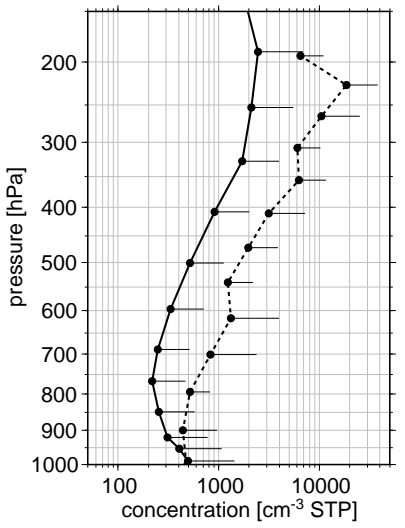

- ECHAM4/MADE $(\geq 0.003 \mu \mathrm{m})$

-..... Clarke UCN $(0.003-3.0 \mu \mathrm{m})$

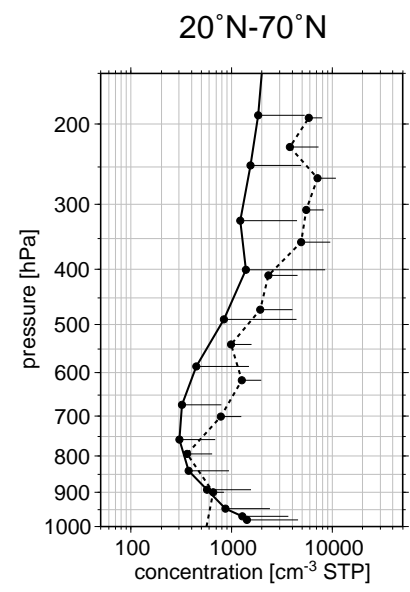

Fig. 11. Vertical profiles of mean aerosol number concentrations (STP conditions: $273 \mathrm{~K}, 1013 \mathrm{hPa}$ ) obtained from various measurement campaigns over the Pacific Ocean (Clarke and Kapustin, 2002) (dashed) and ECHAM4/MADE (solid) for the 3 latitude bands $70^{\circ} \mathrm{S}-20^{\circ} \mathrm{S}$, $20^{\circ} \mathrm{S}-20^{\circ} \mathrm{N}$, and $20^{\circ} \mathrm{N}-70^{\circ} \mathrm{N}$. The error bars depict the standard deviation (positive part shown only).

variability increases with altitude and the median of the observed number concentrations stays within the modeled variability below the 400 to $350 \mathrm{hPa}$ pressure levels. The increased variability is a result of enhanced particle formation by nucleation, which is most effective in the upper troposphere.

The vertical profile of $\mathrm{N}_{15}$ is similar to that of $\mathrm{N}_{5}$ in a qualitative manner. Good agreement between model and observation is found in the lower and middle troposphere below the $600 \mathrm{hPa}$ pressure level. Above this altitude range, modeled number concentrations are systematically lower than observed. In contrast to $\mathrm{N}_{5}$, the modeled variability decreases in the upper troposphere. This indicates, that the modeled aerosol within this size range is hardly influenced by formation of new particles by nucleation.

$\mathrm{N}_{120}$ is about one order of magnitude lower than $\mathrm{N}_{5}$. Up to $350 \mathrm{hPa}$, the modeled median stays within the variability of the measurements. The peak in observed number concentration at about $500 \mathrm{hPa}$ is related to intercontinental long-range transport of particles from boreal forest fires in North America (Petzold et al., 2002). Thus, the elevated number concentrations in this altitude range do not reflect background conditions. Above $350 \mathrm{hPa}$, modeled particle number concentrations as well as corresponding variabilities are systematically smaller than shown by the observations.

The general underestimation of the particle number concentration in the upper troposphere could be a direct result of the prediction of smaller average particle diameters than observed (see Sect. 3.4). Large number concentrations are simulated here for particles smaller than $5 \mathrm{~nm}$. As a direct consequence, this leads to a smaller fraction of larger parti- cles. This implies that the model has to be further improved with respect to parameterizing the particle growth in nucleation bursts in the upper troposphere.

\subsubsection{Pacific Ocean}

Clarke and Kapustin (2002) derived vertical profiles of mean number concentrations of particles with $\mathrm{d}>3 \mathrm{~nm}$ (concentrations adjusted to STP conditions, T=273 K, p=1013 hPa) from several measurement campaigns over the Pacific Ocean. The data set includes ACE- 1 measurements performed in November 1995 (33 flights, 96 profiles), GLOBE-2 data from May 1990 (15 flights, 54 profiles), and PEM-Tropics A and B data from September 1996 and March 1999, respectively (21 flights, 54 profiles (A) and 19 flights, 35 profiles (B)). To distinguish different geographic regimes, Clarke and Kapustin (2002) divided the data into 3 latitude bands: $70^{\circ} \mathrm{S}-20^{\circ} \mathrm{S}$, $20^{\circ} \mathrm{S}-20^{\circ} \mathrm{N}$, and $20^{\circ} \mathrm{N}-70^{\circ} \mathrm{N}$. The longitudinal extent of the regions covers about $\pm 80^{\circ}$ centered around $150^{\circ} \mathrm{W}$. It can be assumed, that these measurements widely reflect conditions with almost no anthropogenic influence. This is due to the large distance to the major source regions at the continental areas. The variability of the number mean concentrations is given by the standard deviations reported by Clarke and Kapustin (2002). A comparison of these data with model results is presented in Fig. 11. The figure shows modeled climatological monthly means extracted for the months covered by the data of the measurement campaigns. The model data were averaged over all grid cells within the individual latitude bands.

Above the southern Pacific $\left(70^{\circ} \mathrm{S}-20^{\circ} \mathrm{S}\right)$, mean particle number concentrations (at STP) increase with height 


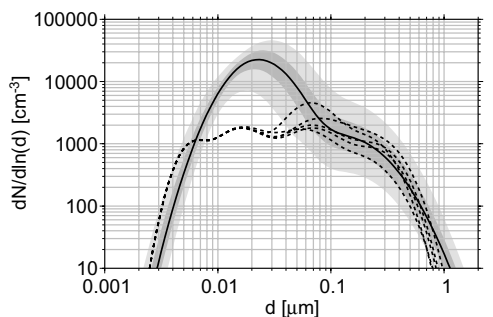

-..... Melpitz Median - ECHAM4/MADE Median

Fig. 12. Typical number size distributions (median) obtained during a period of 17 months for different weather conditions or air mass types, respectively, in Melpitz (Birmili et al., 2001) (dashed) and the corresponding climatological annual median calculated by ECHAM4/MADE (solid). The shaded areas indicate the 25\%- and $75 \%$ - and the $5 \%$ - and $95 \%$-percentiles of the model results.

by about one order of magnitude between the surface and altitudes around the $200 \mathrm{hPa}$ level. This is shown both by the model results and the observations. However, ECHAM4/MADE systematically underestimates particle number concentration by the factor 3.7 (overall average). This might be related to sea salt particles or mineral dust in the size range of the Aitken mode, which are currently not taken into account by the model, but might become important under clean remote conditions.

In the northern hemisphere $\left(20^{\circ} \mathrm{N}-70^{\circ} \mathrm{N}\right)$, a much better quantitative agreement between model and measurements is achieved. On overall average, the particle number concentration is underestimated by a factor of 1.4 by the model. In contrast to the southern hemisphere, there's no systematic over- or underestimation by the model throughout the whole troposphere. Up to about $400 \mathrm{hPa}$, model and observation are conformable within the variability of the number concentrations. Nevertheless, the particle number concentration is systematically underestimated by the model in the upper troposphere. Thus, the major characteristics of differences between modeled and observed profiles follow the characteristics found in the intercomparison of ECHAM4/MADE results with vertical profiles observed during LACE in Central Europe (Sect. 3.3.1).

The observed and simulated tropical profiles $\left(20^{\circ} \mathrm{S}-\right.$ $20^{\circ} \mathrm{N}$ ) show good agreement in the lower troposphere up to about $900 \mathrm{hPa}$. In the middle and upper troposphere, the model systematically underestimates the particle number concentration. Both measurements and simulation show an increase in number concentration between 700 and $200 \mathrm{hPa}$ of about one order of magnitude. On overall average, the observed number concentrations are about 2.8 times higher than calculated by the model.

This comparison shows that ECHAM4/MADE performs reasonably well in the northern hemispheric lower troposphere, but systematically underestimates particle number concentration in the upper troposphere and lowermost stratosphere as well as in the lower troposphere of clean remote areas such as the southern hemisphere. Such a behavior of the model is also suggested by comparison with aircraft measurements (not shown) obtained during the project Interhemispheric Differences in Cirrus Properties from Anthropogenic Emissions (INCA) (Minikin et al., 2003). Hence the model has to be improved for application in remote areas and higher altitudes. The latter particularly concerns the representation of nucleation, the most important source of new particle number concentration in the upper troposphere, and the growth of these fresh particles into the size range of the Aitken mode.

\subsubsection{Particle number concentration - conclusions}

Both the order of magnitude of the particle number concentration and the difference between the individual size classes (modes) is captured by ECHAM4/MADE correctly. The qualitative differences between northern and southern hemisphere and between clean and polluted conditions are reproduced by the model. Modeled and observed number concentrations are in good agreement in the lower and midtroposphere, in particular in polluted continental areas. However, the model underestimates particle numbers in the upper troposphere as well as for clean remote conditions such as for marine conditions in the southern hemispheric boundary layer. A more detailed analysis of the model data shows that the average diameter of the upper tropospheric particles calculated by the model is smaller than found during measurements. This results in many particles slightly below the detection limit of the measurements. A slight reduction of the lower limit (diameter) when calculating particle number from the model data (above a certain threshold dimeter) would result in significantly enhanced number concentrations. This is the case in particular for Aitken mode particles. As concluded in Sect. 3.3.1 this again suggests that the model has to be improved especially with respect to the representation of the particle growth following efficient nucleation events.

\subsection{Size distribution}

\subsubsection{Central Europe}

\section{Melpitz}

A time series of measurements of the aerosol number size distribution at the German site Melpitz $\left(51^{\circ} 32^{\prime} \mathrm{N}, 12^{\circ} 56^{\prime} \mathrm{O}\right)$ has been statistically analyzed by Birmili et al. (2001). The data span a period of 17 months ranging from March 1996 to August 1997. Observed air mass types have been classified by origin and major characteristics. For each type, log-normal size distributions for up to 5 modes were fitted to the measurements, covering the size range from $3 \mathrm{~nm}$ to $0.8 \mu \mathrm{m}$. A nucleation mode $(\approx 3-9 \mathrm{~nm})$, an aged nucleation mode $(\approx 9-30 \mathrm{~nm})$, the Aitken mode $(\approx 30-110 \mathrm{~nm})$, the accumulation mode $(>110 \mathrm{~nm})$, and (occasionally) a sec- 

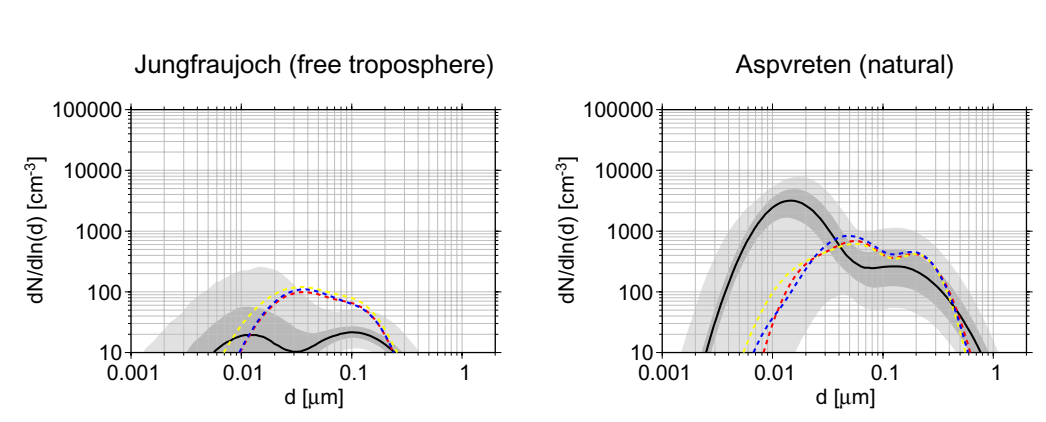

Harwell (natural), London-B (urban),

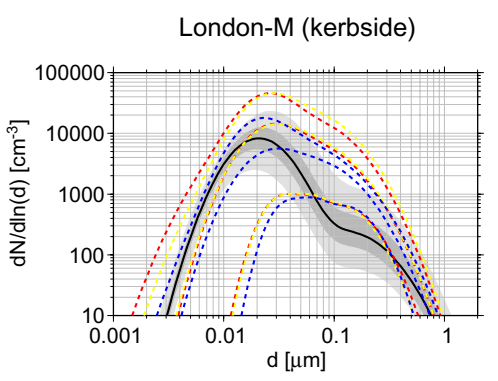

Melpitz (near-city),
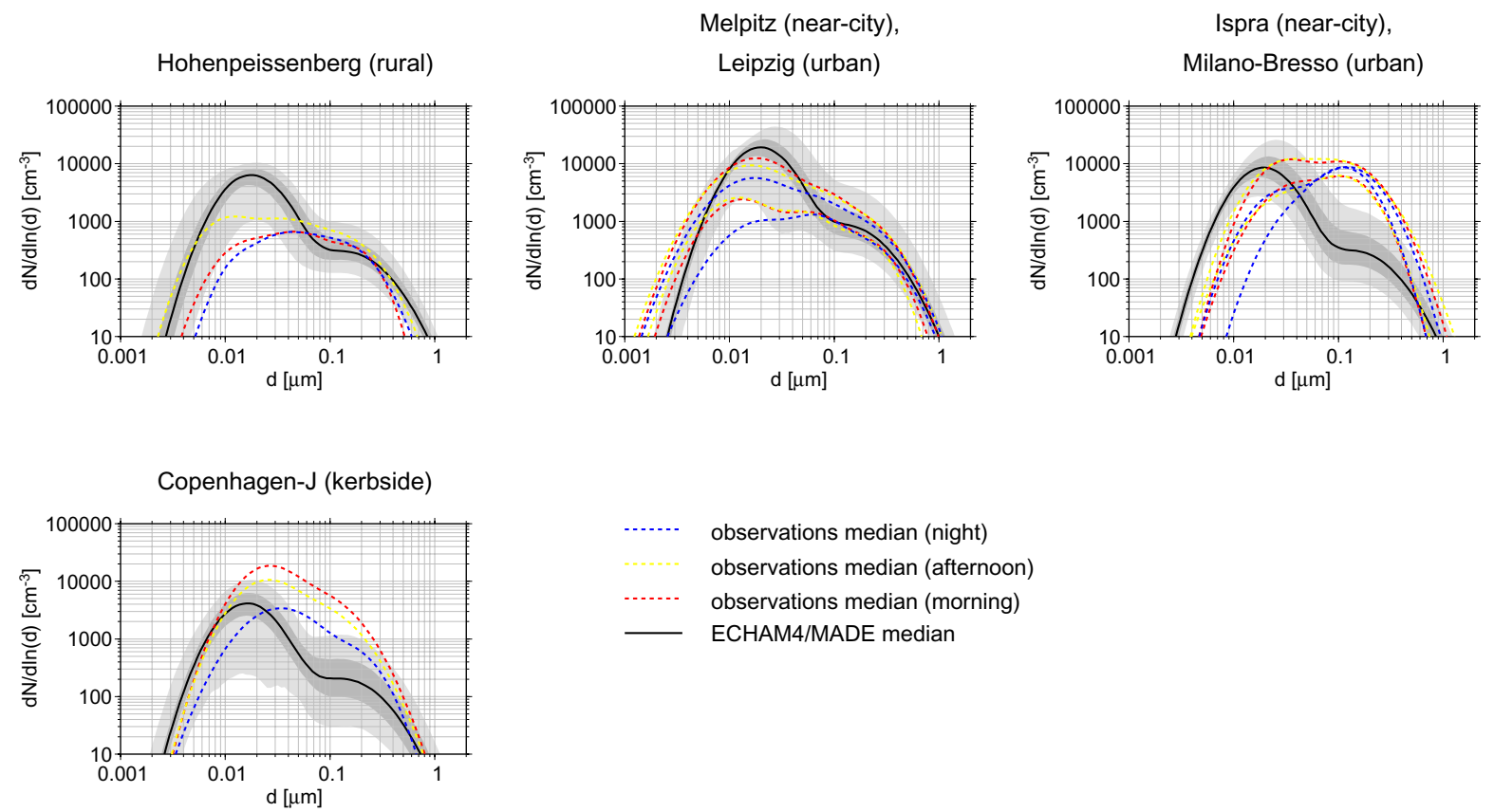

Fig. 13. Particle number size distributions from measurement sites in Europe during winter (December, January, February), obtained from log-normal 3-mode fits during three periods of the day (dashed) (Putaud et al., 2002). The solid line shows the climatological seasonal median number size distributions calculated by ECHAM4/MADE. The shaded areas indicate the 25\%- and 75\%- and the 5\%- and 95\%-percentiles of the model results. Multiple sites in one plot: The highest observed number concentrations refer to kerbside conditions, followed by urban, near-city, rural, and natural conditions.

ond accumulation mode with diameters $>300 \mathrm{~nm}$ are considered. The measurement site Melpitz is surrounded by grasslands, wooded areas, and farmland. The nearest major city (Leipzig, Germany) is $44 \mathrm{~km}$ away. Thus, this station represents rural background conditions rather than urban or other highly polluted conditions. Figure 12 shows the comparison of modeled (calculated from the full 10-year model dataset with a time resolution of $12 \mathrm{~h}$ ) and measured size distributions.

Observed median aerosol number concentrations of particles with diameters between 0.05 and $0.7 \mu \mathrm{m}$ stay completely within the model variability given by the $5 \%$ - and 95\%-percentiles. This is also the case for particles with diameters $<7 \mathrm{~nm}$. Observed number concentrations of particles in the size range 7-50 $\mathrm{nm}$ range between 1000 and $2000 \mathrm{~cm}^{-3}$, whereas the model calculates up to one order of magnitude higher aerosol number concentrations in this size range. Due to the location characteristics of the measurement site Melpitz, the aerosol size distribution has to be assumed to be typical of rural, Central European background conditions rather than of urban conditions. Thus, high number concentrations in the size range of the nucleation and Aitken modes, which are typical for anthropogenic emissions, were not detected. Because of the coarse model grid and the highly variable land use in Central Europe, also major cities are present in the grid cell containing Melpitz. Thus, one would expect higher number concentrations in the size range of the aged nucleation and Aitken mode to be calculated by the model. Nevertheless, the larger portion of the Aitken mode and the accumulation mode calculated by the model are in good agreement with the observations. 

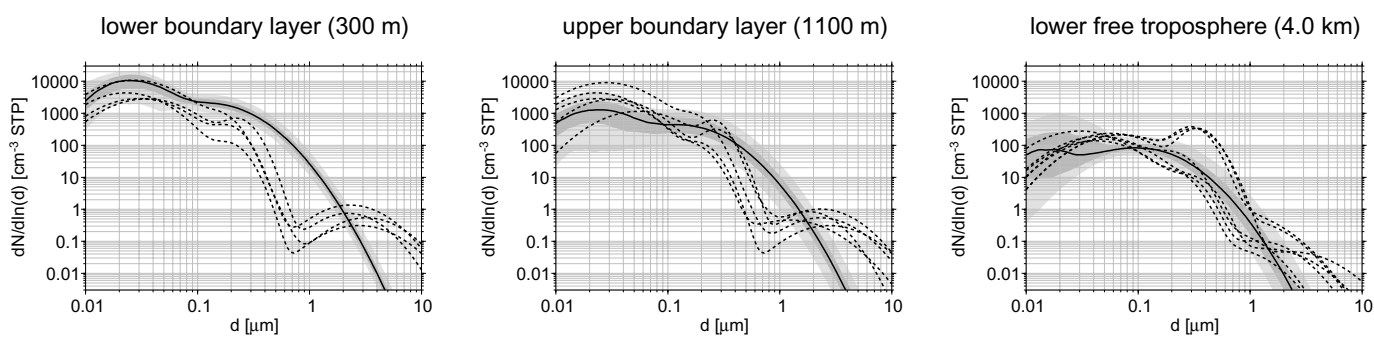

upper free troposphere $(6.1-7.3 \mathrm{~km})$
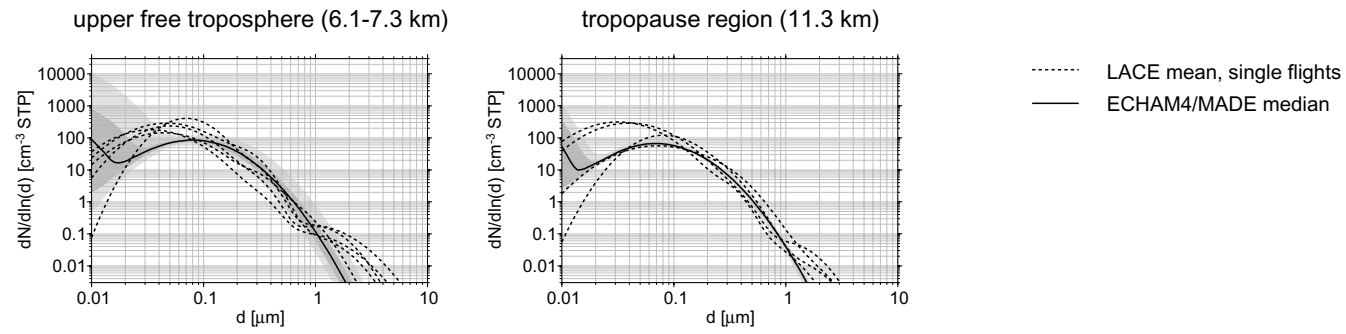

Fig. 14. Number size distributions at different altitudes obtained from averaged measurements during the LACE campaign over northeastern Germany (dashed) (Petzold et al., 2002) and the corresponding median size distribution calculated by ECHAM4/MADE (solid). The shaded areas indicate the $25 \%$ - and $75 \%$ - and the $5 \%$ - and $95 \%$-percentiles of the model results.

\section{Various European sites}

The aerosol measurement data collected by Putaud et al. (2002) consist of data sets, each obtained during a time period of at least six weeks of continuous measurements. According to the classification of Putaud et al. (2002), the measurement locations include natural, rural, near-city, urban, free troposphere, and kerbside sites. Figure 13 shows the median number size distributions obtained from 3-mode lognormal fits to the measurement data during winter (December, January, February). The comparison to measurements during summer is not shown, as the basic conclusions from the comparison are similar to that obtained for the winter data. The observations consist of three number size distributions for each station (night, afternoon, morning) providing insight into the average diurnal variability. At night, observations are expected to represent local background conditions due to low emissions and absent photochemistry. In the morning, the size distributions are expected to be largely influenced by traffic (rush hour). In the afternoon photochemistry is most active (Putaud et al., 2002). The model data consist of climatological seasonal averaged surface values calculated from the full model data set with a time resolution of $12 \mathrm{~h}$ of the respective T30 grid cell containing the measurement site. In the case of the site "Jungfraujoch" (free troposphere) the model data are from the model level coinciding with the station's altitude. The shaded areas indicate the model's variability, $25 \%-/ 75 \%$ - and 5\%-/95\%-percentiles.

The model results represent averages for each grid cell. In case of Central Europe, the type of domain often changes on small spatial scales. This implies that a T30 grid cell contains major cities as well as rural areas. Thus, we expect higher particle number concentrations calculated by the model than usually found in rural or natural regions, but lower number concentrations than observed in urban or kerbside areas.

Most measurements conform with this expectation. The model data corresponding to Harwell, London-B, and London-M for example show lower particle number concentrations than observed in the urban and kerbside areas, but higher particle number concentrations than observed at the natural site Harwell. The same is true for Copenhagen-J (kerbside), Hohenpeissenberg (rural), and Aspvreten (natural). However, for Melptiz (classified as near-city according to Putaud et al., 2002) and Leipzig (urban), the accumulation mode particle number concentration is in good agreement, but the modeled number concentration of the Aitken mode is higher than observed even in the urban environment of Leipzig.

In most cases, ECHAM4/MADE tends to (slightly) underestimate particle number concentration in the size range of the accumulation mode and to overestimate particle number concentration in the Aitken mode. This is probably related to the prescribed size distribution of the primary particles emitted at the surface. For instance, BC particles from fossil fuel combustion in the model are currently predominantly emitted in the size range of the Aitken mode (Table 2), which refers to a size distribution typically found close to the sources. The consideration of a more aged size distribution rather than the currently used size distribution of fresh emitted particles might improve the agreement with observations. However, it should be kept in mind that the observational data represent measurements of individual sites, which strongly depend on the local environment, whereas the model averages over large areas. 


\section{Northeast Germany}

With the instrumentation used during the measurement campaign LACE (see Sect. 3.3), number size distributions in the size range of the Aitken mode to coarse mode could be determined. To these data, Petzold et al. (2002) fitted trimodal lognormal size distributions for various altitudes and each individual measurement flight. Figure 14 shows the log-normal size distributions fitted to the measurement data of the individual flights and the median size distribution calculated from $12 \mathrm{~h}$ averages of the ECHAM4/MADE data. Five altitude ranges are shown: lower boundary layer (300 m), upper boundary layer $(1.1 \mathrm{~km})$, lower free troposphere $(4.0 \mathrm{~km})$, upper free troposphere $(6.1-7.3 \mathrm{~km})$, and tropopause region $(11.3 \mathrm{~km})$.

In the lower and upper boundary layer, the modeled median number concentrations of particles smaller than $100 \mathrm{~nm}$ or $400 \mathrm{~nm}$, respectively, mostly stay within the variability of the measurements given by the individual flights. However, the median diameter of the modeled accumulation mode is about 1.5 times smaller compared to the measurements and the fitted standard deviation of the observed accumulation mode $(\sigma \approx 1.3)$ is smaller than the fixed sigma chosen in $\operatorname{MADE}(\sigma=2.0)$. This leads to an overestimation of the number of larger accumulation mode particles by the model.

During three flights, enhanced number concentrations of aged accumulation mode particles were observed resulting from long-range transport of boreal fires in North America. This is mostly apparent in the lower free troposphere. These flights do not represent normal background conditions and should not be taken into account when comparing to the model data. Excluding these data, free tropospheric particle number concentrations mostly agree within the variability ranges. The free tropospheric median diameter of the Aitken mode is 2-3 times smaller compared to measurements. The variability and the modal diameter of the modeled Aitken mode increase or decrease with height, respectively. This indicates an increasing nucleation activity.

In the upper free troposphere and the tropopause region, the modeled modal median diameters of both modes are even smaller than in the lower free troposphere. This is due to nucleation activity increasing with altitude in the model producing a large number of very small particles, which are assigned to the models Aitken mode. However, the particle number concentrations modeled in the upper free troposphere and tropopause region mostly agree with the observations within the variability up to particle diameters of approximately $1 \mu \mathrm{m}$.

We conclude from this intercomparison of the number size distributions for different altitudes, that ECHAM4/MADE performs reasonably well in the boundary layer and middle troposphere in respect of the modal median diameters and the maximum particle number concentrations. However, the standard deviation currently prescribed for the accumulation mode of the model is much larger (2.0) than the standard de- viation fitted to the observed accumulation mode (1.3). In addition, there are still some deficiencies in the upper troposphere and tropopause region. Here, the model underestimates the modal median diameters of both modes by a factor of 2-3. This unveils a principle problem of the modal concept of MADE using two modes: the assignment of a large number of freshly nucleated particles to the Aitken mode shifts the modeled mode towards smaller modal median diameters. Thus, an aged Aitken mode cannot be represented properly by the model. An extension of the bimodal concept towards a trimodal representation of the submicrometer aerosol might help reducing this problem. An other (complementary) approach could be a parameterization not only of nucleation events, but also of the subsequent growth (aging) of the newly formed particles before transferring these particles into the Aitken mode of MADE.

\subsubsection{Aerosol states in the free troposphere}

From the measurement data obtained during LACE, Schröder et al. (2002) derived typical and extreme states of the free tropospheric aerosol for continental summer conditions. Plotting the number of particles larger than $100 \mathrm{~nm}$ $\left(\mathrm{n}_{100}\right)$ versus the particle number of the size fraction $3-$ $100 \mathrm{~nm}\left(\mathrm{n}_{3}-\mathrm{n}_{100}\right)$, Schröder et al. (2002) found most of the measurements within a triangular shaped area. This triangular shape was explained by Schröder et al. (2002) according to the schematic shown in Fig. 15. While the center of the triangle represents the most typical (median) aerosol state, the three corners correspond to the extreme states. The state "SCA" is characterized by low number concentrations in both size classes, which is typically found after scavenging of particles by cloud droplets. The state "NUC" shows a large number of small particles and only few particles in the large size range. This state is dominated by fresh aerosol formed by nucleation. In contrast, the "ACC" state is typical for aged aerosol, with a high number concentration in the accumulation mode and a moderate number concentration in the size range of the Aitken mode. The most frequent aerosol state is represented by "MED". The median of the measured particle number concentrations amounts to about $300 \mathrm{~cm}^{-3}$ in the size range $3-100 \mathrm{~nm}\left(\mathrm{n}_{3}-\mathrm{n}_{100}\right)$ and about $60 \mathrm{~cm}^{-3}$ for particles larger than $100 \mathrm{~nm}\left(\mathrm{n}_{100}\right)$.

The modeled aerosol states in the free troposphere obtained from simulated $12 \mathrm{~h}$ averages show a similar triangular shape. However, the median particle number concentration $\mathrm{n}_{100}$ amounts to $28 \mathrm{~cm}^{-3}$, whereas the corresponding observed number is about twice as high. The median of $\mathrm{n}_{3}-\mathrm{n}_{100}$ is $405 \mathrm{~cm}^{-3}$, which is about factor 1.4 higher than observed. Again, this shows, that the average particle diameters simulated by the model are smaller than observed. This leads to an underestimation of particles above a given threshold diameter (here $100 \mathrm{~nm}$ ) and an overestimation of particles below this threshold diameter. 

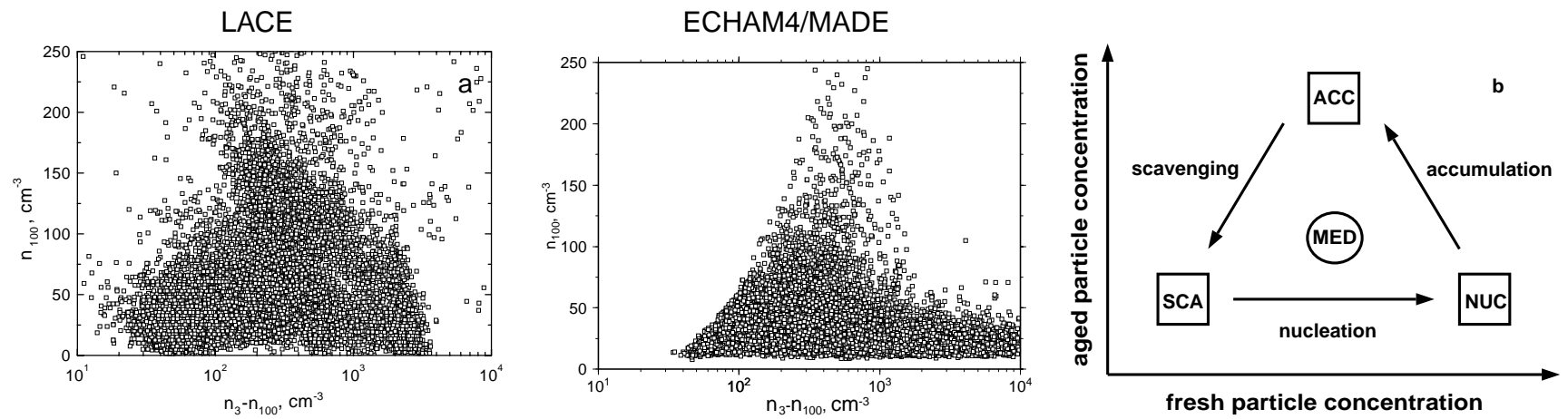

Fig. 15. Scatterplot of the particle number concentrations in the free troposphere (altitude range 4-10 km) for the domain of the LACE campaign. The plots depict particle number concentration of particles with $\mathrm{d}>100 \mathrm{~nm}\left(\mathrm{n}_{100}\right)$ versus particle number concentration of particles in the size range 3-100 $\mathrm{nm}\left(\mathrm{n}_{3}-\mathrm{n}_{100}\right)$. From left to right: LACE, ECHAM4/MADE, schematic view of the aerosol states in the free troposphere. The left and right figures are taken from Schröder et al. (2002). For details see text.

In summary, ECHAM4/MADE is able to reproduce the major features of the extreme and typical aerosol states in the free troposphere. Therefore, the most important processes controlling the aerosol size distribution seem to be represented by the model. However, the model underestimates the number concentration of aged accumulation mode particles by about factor 2 , which is consistent with the differences already found in the upper tropospheric number concentrations when comparing vertical profiles (Sect. 3.3). In contrast to the underestimation of upper tropospheric number concentration of Aitken mode particles (threshold $5 \mathrm{~nm}$ ), the median particle number concentration in the size range below $100 \mathrm{~nm}$ is slightly overestimated (threshold $3 \mathrm{~nm}$ ). This approves the high sensitivity of the modeled particle number concentration above a certain diameter to the threshold diameter chosen, as many particles are modeled in the size range $3-5 \mathrm{~nm}$. This is consistent with the underestimation of particles larger than $5 \mathrm{~nm}$ in this altitude range described in Sect. 3.3.

\section{Conclusions}

The aerosol dynamics module MADE has been coupled to the general circulation model ECHAM4. This allows for a more detailed representation of atmospheric aerosols and related size-dependent physical and chemical processes than in previous model versions including the mass-based aerosol module FL96. The numerical efficiency of this new model system allows for multi annual integrations required for investigating the Earth's climate. ECHAM4/MADE takes into account sulfate, ammonium, nitrate, sea salt, mineral dust, black carbon, organic matter, and aerosol liquid water and calculates particle number concentration and size distribution for two log-normal modes in the submicrometer range. In addition to advection, diffusion, and convective transport of the particles, also size-dependent wet and dry deposition are considered. Coagulation within modes (intramodal) and between the different modes (intermodal) is calculated. New particle formation by binary nucleation of sulfuric acid and water and the condensation of sulfuric acid vapor onto the surface of pre-existing particles are considered. The implemented aerosol chemistry includes sulfate production by oxidation of $\mathrm{SO}_{2}$ via reaction with $\mathrm{H}_{2} \mathrm{O}_{2}$ and $\mathrm{O}_{3}$ in cloud droplets and oxidation of $\mathrm{SO}_{2}$ via reaction with $\mathrm{OH}$ in the gas phase. Emissions at the surface include gaseous precursors such as $\mathrm{SO}_{2}$, DMS, or $\mathrm{NH}_{3}$, and particulate matter. Sourcedependent size distributions are used to derive the number concentration of primary particles from the mass emitted.

In order to evaluate the results from a first 10-year integration performed with the new model system, the model output of ECHAM4/MADE has been compared to various observations such as mass concentration of simulated aerosol components, particle number concentration or number size distribution. The results of this intercomparison can be summarized as follows: ECHAM4/MADE performs reasonably well in the lower and middle troposphere above polluted continental regions in the northern hemisphere. Modeled mass concentrations and particle number concentrations show a reasonably good agreement with the measurements in respect of geographical patterns, absolute values and the seasonal cycle. In the upper troposphere and tropopause region, as well as in the lower troposphere in clean remote areas such as the southern hemispheric Pacific Ocean, the model tends to underestimate the particle number concentration. The comparison with observations reveals that the simulated sizes of particles in the upper troposphere and the tropopause region are too small. This results in an underestimation of the number concentration of particles larger than a given threshold diameter (e.g. $5 \mathrm{~nm}$ ). Freshly nucleated particles do not grow quick enough in this altitude range. This inefficient growth of freshly nucleated particles seems to be related to the coarse spatial and temporal scales of the GCM. A parameterization of the growth of these particles into the size-range of the Aitken mode within sub-grid scale nucleation bursts and/or 
the introduction of a third submicrometer mode, a nucleation mode, should improve the performance of ECHAM4/MADE in these regimes. These improvements will be subject to further developing of the model.

Clean remote regions where the model tends to underestimate particle number concentration have only little effect on the total budgets of fine particles, which are dominated by sulfate, POM, and BC from air pollution. Thus, ECHAM4/MADE is already a suitable tool for further investigations of these budgets. Aerosol properties such as chemical composition, particle number concentration, and size distribution can be properly investigated especially for the polluted northern hemispheric lower troposphere. Using ECHAM4/MADE, the contribution of all individual processes, in particular aerosol dynamics, to the sources and sinks of submicrometer particles can be determined easily.

The total mass concentrations of the submicrometer aerosol simulated by MADE and the previously used massbased aerosol module FL96 considering the same emission inventories are similar. Differences in the total burdens of $\mathrm{SO}_{4}, \mathrm{BC}$, and POM are below 20\%. Nevertheless, significant progress was achieved by the implementation of MADE compared to the previous model version: In addition to the aerosol mass concentration predicted by FL96, MADE provides information about particle number concentration and size-distribution. The wide variability of aerosol sizedistributions simulated all over the globe shows that assuming a constant size-distribution to estimate particle number concentration from aerosol mass gives only a crude estimate. The prediction of particle size-distributions strengthens the ability to calculate size-dependant processes such as wet deposition on a more physical basis instead of using rather simplified parameterizations (e.g. assuming constant scavenging factors). The more physical treatment of aerosol-related processes is needed to make further progress in understanding the effect of aerosol on clouds, atmospheric chemistry, and climate.

Acknowledgements. We thank L. Ganzeveld for his help on implementing the dry deposition in ECHAM4/MADE and A. Clarke and $\mathrm{V}$. Capustin for providing the aerosol measurements performed over the Pacific Ocean. We are grateful to A. Petzold and A. Minikin for providing aerosol number concentrations observed during LACE and INCA. We also thank J. Feichter for the provision of the ECHAM4 aerosol mass module and his helpful comments on the manuscript. We gratefully acknowledge U. Lohmann for making the extended ECHAM4 cloud module available. The provision of MADE by the University of Cologne (EURAD-project) is kindly acknowledged. We also wish to thank the executives of the programmes EMEP and IMPROVE for making their measurement data available to the public on the Internet. This work was supported by the German Helmholtz-Gemeinschaft Deutscher Forschungszentren (HGF) and the Deutsches Zentrum für Luftund Raumfahrt (DLR) within the project PAZI and by the Junior Research Group SeaKLIM, which is funded by the HGF, DLR, and the University of Bremen. All model calculations were per- formed on the HLRE, supported by the German Federal Ministry of Education and Research (BMBF) and DKRZ (Hamburg, Germany).

Edited by: W. T. Sturges

\section{References}

Ackermann, I. J., Hass, H., Memmesheimer, M., Ebel, A., Binkowski, F. S., and Shankar, U.: Modal Aerosol Dynamics for Europe: Development and first applications, Atmos. Environ., 32, 2981-2999, 1998.

Adams, P. J. and Seinfeld, J. H.: Predicting global aerosol size distributions in general circulation models, J. Geophys. Res., 107(D19), doi:10.1029/2001JD001010, 2002.

Adams, P. J., Seinfeld, J. H., and Koch, D. M.: Global concentrations of tropospheric sulfate, nitrate and ammonium simulated in a general circulation model, J. Geophys. Res., 104, $13791-$ $13823,1999$.

Benkovitz, C. M., Berkowitz, C. M., Easter, R. C., Nemesure, S., Wagener, R., and Schwartz, S.: Sulfate over the North Atlantic and adjacent continental regions: Evaluation for October and November 1986 using a three-dimensional model driven by observation-derived meteorology, J. Geophys. Res., 99, $20725-$ $20756,1994$.

Berge, E.: Coupling of wet scavenging of sulphur to clouds in a numerical weather prediction model, Tellus, 45B, 1-22, 1993.

Binkowski, F. S.: Science Algorithms of the EPA Models-3 Community Multiscale Air Quality (CMAQ) Modelling System, edited by: Byun, D. W. and Ching J. K. S., EPA/600/R-99/030, United States Environmental Protection Agency (EPA), Washington, D.C., Office of Research and Development, 1999.

Binkowski, F. S. and Shankar, U.: The Regional Particulate Matter Model, 1. Model description and preliminary results, J. Geophys. Res., 100, 26 191-26 209, 1995.

Binkowski, F. S. and S. J, Roselle.: Models-3 Community Multiscale Air Quality (CMAQ) model aerosol component, 1. Model description, J. Geophys. Res., 108(D6), doi:10.1029/2001JD001409, 2003.

Binkowski, F. S., Kreidenweis, S. M., Harrington, D. Y., and Shankar, U.: Comparison of new particle formation mechanisms in the regional particulate matter, Presentation at the Fifteenth Annual Conference of the American Association for Aerosol Research, Orlando Florida, 14-18 October, 1996.

Birmili, W., Wiedensohler, A., Heitzenberg, J., and Lehmann, K.: Atmospheric particle number size distribution in central Europe: Statistical relations to air masses and meteorology, J. Geophys. Res., 106, 32 005-32 018, 2001.

Bond, T. C., Streets, D. G., Yarber, K. F., Nelson, S. M., Woo, J.-H., and Klimont, Z.: A technology-based global inventory of black and organic carbon emissions from fossil fuel, J. Geophys. Res., 109, D14203, doi:10.1029/2003JD003697, 2004.

Bouwman, A. F., Lee, D. S., Asman, W. A. H., Dentener, F. J., van der Hoek, K. W., and Olivier, J. G. J.: A global high-resolution emission inventory for ammonia, Global Biogeochem. Cycles, 11, 561-587, 1997.

Brinkop, S. and Sausen, R.: A Finite Difference Approximation for Convective Transports Which Maintains Positive Tracer Concentrations, Beitr. Phys. Atmosph., 70, 245-248, 1997. 
Chin, M., Rood, R. B., Lin, S.-J., Müller, J.-F., and Thompson, A.: Atmospheric sulfur cycle simulated in the global model GOCART: Model description and global properties, J. Geophys. Res., 105, 24 671-24 687, 2000.

Chung, S. H. and Seinfeld, J. H.: Global distribution and climate forcing of carbonaceous aerosols, J. Geophys. Res., 107(D19), doi:10.1029/2001JD001397, 2002.

Clarke, A. D. and Kapustin, V. N.: A Pacific Aerosol Survey. Part I: A Decade of Data on Particle Production, Transport, Evolution, and Mixing in the Troposphere, J. Atmos. Sci., 59, 363382, 2002.

Cooke, W. F. and Wilson, J. J. N.: A global black carbon aerosol model, J. Geophys. Res., 101, 19395-19409, 1996.

Cooke, W. F., Liousse, C., and Cachier, H.: Construction of a $1^{\circ} \times 1^{\circ}$ fossil fuel emission data set for carbonaceous aerosol and implementation and radiative impact in the ECHAM4 model, J. Geophys. Res., 104, 22 137-22 162, 1999.

Dentener, F.: Heterogeneous chemistry in the troposphere, dissertation, University of Utrech, Netherlands, ISBN 90-393-0317-7, 1993.

Ebel, A., Elbern, H., Hass, H., Jakobs, H. J., Memmesheimer, M., Laube, M., Oberreuter, A., and Piekorz, G.: Simulation of chemical transformation and transport of air pollutants with the model system EURAD, Transport and Chemical Transformation of Pollutants in the Troposphere, edited by: Borell, P., Borell, P. M., and Midgley, P., Vol. 7, Tropospheric Modelling and Emission Estimation, Springer, Berlin, Germany, 27-45, 1997.

EEA (European Environment Agency): Air pollution in Europe 1990-2000, ISBN 92-9167-635-7, 2003.

EMEP Co-operative Programme for Monitoring and Evaluation of the Long-Range Transmission of Air Pollutants in Europe: Measurement of Particular Matter, Status Report 2003, EMEP/CCCReport 5/2003, edited by: Kahnert, M., Norwegian Institute for Air Research (NILU), Kjeller, Norway, 2003.

Feichter, J. and Roeckner, E.: Nonlinear Aspects of the Climate Response to Greenhouse Gas and Aerosol Forcing, J. Clim., 17, 2384-2398, 2004.

Feichter, J., Kjellström, E., Rodhe, H., Dentener, F., Lelieveld, J., and Roelofs, G.-J.: Simulation of the tropospheric sulfur cycle in a global climate model, Atmos. Environ., 30, 1693-1707, 1996.

Feichter, J., Lohmann, U., and Schult, I.: The atmospheric sulfur cycle in ECHAM-4 and its impact on the shortwave radiation, Clim. Dyn., 13, 235-246, 1997.

Ganzeveld, L. and Lelieveld, J.: Dry deposition parameterization in a chemistry general circulation model and its influence on the distribution of reactive trace gases, J. Geophys. Res., 100, 20 999-21 012, 1995.

Ginoux, P., Chin, M., Tegen, I., Prospero, J., Holben, B., Dubovik, O., and Lin, S.-J.: Sources and distributions of dust aerosols simulated with the GOCART model, J. Geophys. Res., 106, 20 255$20273,2001$.

Gong, S. L. and Barrie, L. A.: Modeling sea-salt aerosols in the atmosphere, 1. Model development, J. Geophys. Res., 102, 38053818, 1997.

Guenther, A., Hewitt, C. N., Erickson, D., et al.: A global model of natural volatile organic compound emissions, J. Geophys. Res., 100, 8873-8892, 1995.

Hao, W. M., Liu, M. H., and Crutzen, P. J.: Estimates of annual and regional releases of $\mathrm{CO}_{2}$ and other trace gases to the atmosphere from fires in the tropics, based on the FAO statistics for the period 1975-1980, Fire in the tropical biota, in: Ecosystem processes and global challenges, edited by: Goldammer, J. G., Springer, New York, USA, 440-462, 1990.

Hein, R., Dameris, M., Schnadt, C., Land, C., Grewe, V., Köhler, I., Ponater, M., Sausen, R., Steil, B., Landgraf, J., and Brühl, C.: Results of an interactively coupled atmospheric chemistrygeneral circulation model: Comparison with observations, Ann. Geophys., 19, 435-457, 2001,

SRef-ID: 1432-0576/ag/2001-19-435.

Hendricks, J., Kärcher, B., Döpelheuer, A., Feichter, J., Lohmann, U., and Baumgardner, D.: Simulating the global atmospheric black carbon cycle: a revisit to the contribution of aircraft emissions, Atmos. Chem. Phys., 4, 2521-2541, 2004,

SRef-ID: 1680-7324/acp/2004-4-2521.

Henning, S., Weingartner, E., Schmidt, S., Wendisch, M., Gäggeler, H. W., and Baltensperger, U.: Size-dependent aerosol activation at the high-alpine site Jungfraujoch (3580 $\mathrm{m}$ a.s.1.), Tellus, 54B, 82-95, 2002.

Hess, M., Koepke, P., and Schult, I.: Optical properties of aerosols and clouds: The software package OPAC, Bull. Am. Meteorol. Soc., 79, 831-844, 1998.

Hildemann, L. M., Markowski, G. R., Jones, M. C., and Cass, G. R.: Submicrometer aerosol mass distributions of emissions from boilers, fireplaces, automobiles, diesel trucks, and meat cooking operations, Aerosol Sci. Technol., 14, 138-152, 1991.

IPCC (Intergovernmental Panel on Climate Change 2001): Climate Change 2001, The Scientific Basis, Contribution of Working Group I to the Third Assessment Report of the Intergovernmental Panel on Climate Change, edited by: Houghton, J. T., Ding, Y., Griggs, D. J., Noguer, M., van der Linden, P. J., Dai, X., Maskell, K., and Johnson, C. A., Cambridge University Press, Cambridge, United Kingdom and New York, USA, 2001.

Jacobson, M. Z.: GATOR-GCMM: A global- trough urban-scale air pollution and weather forecast model, 1. Model design and treatment of subgrid soil, vegetation, roads, rooftops, water, sea ice and snow, J. Geophys. Res, 106, 5385-5401, 2001.

Jaenicke, R.: Tropospheric aerosols, in: Aerosol-Cloud-Climate Interactions, edited by: Hobbs, P. V., Academic Press, San Diego, CA, USA, 1-31, 1993.

Kettle, A. J., Andreae, M. O., Amouroux, D., et al.: A preliminary global database of sea surface dimethyl sulfide as a function of latitude, longitude, and month, EOS Trans. AGU, 77 (46), 417, Fall Meet. Suppl., 1996.

Kim, Y. P., Seinfeld, J. H., and Saxena, P.: Atmospheric gas/aerosol equilibrium I. Thermodynamic model, Aerosol Sci. Technol., 19 (2), 157-181, 1993a.

Kim, Y. P., Seinfeld, J. H., and Saxena, P.: Atmospheric gas/aerosol equilibrium II. Analysis of common approximations and activity coefficient calculation methods, Aerosol Sci. Technol., 19 (2), 182-198, 1993b.

Köhler, I., Dameris, M., Ackermann, I., and Hass, H.: Contribution of road traffic emissions to the atmospheric black carbon burden in the mid-1990s, J. Geophys. Res., 106, 17 997-18 014, 2001.

Koop, T., Luo, B. P., Tsias, A., and Peter, T.: Water activity as the determinant for homogeneous ice nucleation in aqueous solutions, Nature, 406, 611-614, 2000.

Kulmala, M., Laaksonen, A., and Pirjola, L.: Parameterizations for sulfuric acid/water nucleation rates, J. Geophys. Res., 103, 8301- 
8308, 1998.

Liousse, C., Penner, J. E., Chuang, C., Walton, J. J., Eddleman, H., and Cachier, H.: A global three-dimensional model study of carbonaceous aerosols, J. Geophys. Res., 101, 19411-19432, 1996.

Lohmann, U.: Possible Aerosol Effects on Ice Clouds via Contact Nucleation, J. Atmos. Sci., 59, 647-656, 2002.

Lohmann, U. and Kärcher, B.: First interactive simulations of cirrus clouds formed by homogeneous freezing in the ECHAM general circulation model, J. Geophys. Res., 107(D10), doi:10.1029/2001JD000767, 2002.

Lohmann, U., Feichter, J., Chuang, C. C., and Penner, J. E.: Prediction of the number of cloud droplets in the ECHAM GCM, J. Geophys. Res., 104, 9169-9198, 1999.

Malm, W. C., Pitchford, M. L., Scruggs, M., et al.: Spatial and seasonal patterns and temporal variability of haze and its constituents in the United States, Report III, Cooperative Institute for Research in the Atmosphere, Colorado State University, ISSN 0737-5352-47, 2000.

Metzger, S. M., Dentener, F. J., Lelieveld, J., and Pandis, S. N.: Gas/aerosol partitioning I, A computationally efficient model, J. Geophys. Res., 107, doi:10.1029/2001JD001102, 2002a.

Metzger, S. M., Dentener, F. J., Jeuken, A., Krol, M., and Lelieveld, J.: Gas/aerosol partitioning II: Global modelling results, J. Geophys. Res., 107(D16), doi:10.1029/2001JD001103, 2002b.

Minikin, A., Petzold, A., Ström, J., Krejci, R., Seifert, M., van Velthoven, P., Schlager, H., and Schumann, U.: Aircraft Observations of the Upper Tropospheric Fine Particle Aerosol in the Northern and Southern Hemispheres at Midlatitudes, Geophys. Res. Lett., 30, 1503, doi:10.1029/2002GL016458, 2003.

Monahan, E. C., Spiel, D. E., and Davidson, K. L.: A model of marine aerosol generation via whitecaps and wave disruption, Oceanic Whitecaps, edited by: Monahan, E. C. and Mac Niocaill, G., D. Reidel, Norwell, Massachusetts, USA, 1986.

Napari, I., Noppel, M., Vehkamäki, H., and Kulmala, M.: Parameterization of ternary nucleation rates for $\mathrm{H}_{2} \mathrm{SO}_{4}-\mathrm{NH}_{3}-\mathrm{H}_{2} \mathrm{O}$ vapors, J. Geophys. Res., 107(D19), doi:10.1029/2002JD002132, 2002.

Nenes A., Pandis, S. N., and Pilinis, C.: ISORROPIA: A new thermodynamic equilibrium model for multiphase multicomponent inorganic aerosols, Aquat. Geoch., 4, 123-152, 1998.

Penner, J. E., Chuang, C. C., and Grant, K.: Climate forcing by carbonaceous and sulfate aerosols, Clim. Dyn., 14, 839-851, 1998.

Petzold, A., Fiebig, M., Flentje, H., Keil, A., Leiterer, U., Schröder, F., Stifter, A., Wendisch, M., and Wendling, P.: Vertical variability of aerosol properties observed at a continental site during LACE 98, J. Geophys. Res., 107(D21), doi:10.1029/2001JD001043, 2002.

Putaud, J.-P., Dingenen, R. V., Baltensperger, U., et al.: A European Aerosol Phenomenology, physical and chemical characteristics of particulate matter at kerbside, urban, rural and background sites in Europe, joint research centre, European Commission, EUR 20411 EN, 2002.

Raes, F., Van Dingenen, R., Vignati, E., Wilson, J., Putaud, J.-P., Seinfeld, J. H., Adams, P.: Formation and cycling of aerosols in the global troposphere, Atmos. Environ., 34, 4215-4240, 2000.

Rasch, P. J. and Williamson, D. L.: Computational aspects of moisture transport in global models of the atmosphere, Quart. J. R. Met. Soc., 116, 1071-1090, 1990.
Roeckner, E., Arpe, K., Bengtsson, L., Christoph, M., Claussen, M., Dümenil, L., Esch, M., Giorgetta, M., Schlese, U., and Schulzweida, U.: The atmospheric general circulation model ECHAM-4: Model description and simulation of present-day climate, Max Planck Institute for Meteorology, Report No. 218, Hamburg, Germany, ISSN 0937-1060, 1996.

Roeckner, E., Bäuml, G., Bonaventura, L., Brokopf, R., Esch, M., Giorgetta, M., Hagemann, S., Kirchner, I., Kornblueh, L., Manzini, E., Rhodin, A., Schlese, U., Schulzweida, U., and Tompkins, A.: The atmospheric general circulation model ECHAM5, Part I: Model description, Max Planck Institute for Meteorology, Report No. 349, Hamburg, Germany, ISSN 09371060, 2003.

Saxena, P., Hudischewskyj, A. B., Seigneur, C., and Seinfeld, J. H.: A comparative study of equilibrium approaches to the chemical characterization of secondary aerosols, Atmos. Environ., 20, 7, 1471-1483, 1986.

Schell, B., Ackermann, I. J., Hass, H., Binkowski, F. S., and Ebel, A.: Modeling the formation of secondary organic aerosol within a comprehensive air quality model system, J. Geophys. Res., 106(D22), doi:10.1029/2001JD000384, 2001.

Seinfeld, J. H. and Pandis, S. N.: Atmospheric Chemistry and Physics - From Air Pollution to Climate Change, John Wiley and Sons, Inc., New York, USA, 1998.

Schröder, F., Kärcher, B., Fiebig, M., and Petzold, A.: Aerosol states in the free troposphere at northern midlatitudes, J. Geophys. Res., 107(D21), doi:10.1029/2000JD000194, 2002.

Schulz, M., Balkanski, Y. J., Guelle, W., and Dulac, F.: Role of aerosol size distribution and source location in a threedimensional simulation of a Saharan dust episode tested against satellite-derived optical thickness, J. Geophys. Res., 103, 10 579-10 592, 1998.

Slinn, S. A. and Slinn, W. G. N.: Prediction for particle deposition on natural waters, Atmos. Environ., 14, 1013-1016, 1980.

Spiro, P. A., Jacob, D. J., and Logan, J. A.: Global inventory of sulfur emissions with $1^{\circ} \times 1^{\circ}$ resolution, J. Geophys. Res., 97, 6023-6036, 1992.

Stier, P., Feichter, J., Kinne, S., Kloster, S., Vignati, E., Wilson, J., Ganzeveld, L., Tegen, I., Werner, M., Balkanski, Y., Schulz, M., and Boucher, O.: The aerosol-climate model ECHAM5-HAM, Atmos. Chem. Phys., 5, 1125-1156, 2005,

SRef-ID: 1680-7324/acp/2005-5-1125.

Takemura, T., Okamoto, H., Maruyama, Y., Numaguti, A., Higurashi, A., and Nakajima, T.: Global three-dimensional simulation of aerosol optical thickness distribution of various origins, J. Geophys. Res., 105, 17 853-17 873, 2000.

Tanre, D., Geleyn, J.-F., and Slingo, J. M.: First results of the introduction of an advanced aerosol-radiation interaction in the ecmwf low resolution global model, in: Aerosols and Their Climatic Effects, edited by: Gerber, H. and Deepak, A., A. Deepak, Hampton, Va, USA, 133-177, 1984.

Tiedtke, M.: A comprehensive mass flux scheme for cumulus parameterization in large-scale models, Mon. Weather Rev., 117, 3040-3061, 1989.

Vehkamäki, H., Kulmala, M., Napari, I., Lehtinen, K. E. J., Timmreck, C., Noppel, M., and Laaksonen, A.: An improved parameterization for sulfuric acid-water nucleation rates for tropospheric and stratospheric conditions, J. Geophys. Res., 107(D22), doi:10.1029/2002JD002184, 2002. 
Weber, R. J., Marti, J. J., McMurry, P. H., Eisele, F. L., Tanner, D. J., and Jefferson, A.: Measurements of new particle formation and ultrafine particle growth rates at clean continental site, J. Geophys. Res., 102, 4375-4385, 1997.

Whitby, E. R., McMurray, P. H., Shankar, U., and Binkowski, F. S.: Modal Aerosol Dynamics Modelling, Technical Report 600/391/020, (available as NTIS PB91-161729/AS from Natl. Tech. Inf. Serv. Springfield, VA), Atmospheric Research and Exposure Assess. Lab., US Environmental Protection Agency, Research Triangle Park, NC, USA, 1991.
Wilson, J., Cuvelier, C., and Raes, F.: A modeling study of global mixed aerosol fields, J. Geophys. Res., 106, 34 081-34 108, 2001. 